\title{
Updating Expectations: An Analysis of Post-9/11 Returns
}

\author{
Jarl Kallberg, Crocker H. Liu, and Paolo Pasquariello ${ }^{1}$
}

November 2, 2005

\footnotetext{
${ }^{1}$ Associate Professors of Finance, Department of Finance, Stern School of Business, and Assistant Professor of Finance, Ross School of Business at University of Michigan. Please address comments to Jarl Kallberg at jkallber@stern.nyu.edu. Crocker Liu would like to thank the Salomon Center at the Stern School for financial support. We are grateful to Sreedhar Bharath, Richard Buttimer, Dennis Capozza, Ron Donohue, Ned Elton, Jeff Fisher, Hugh Kelly, Stephen Melpezzi, Norman Miller, Ron Racster, Lynn Sagalyn, Anthony Sanders, Greg Schwann, William Strange, Charles Trzcinka, and seminar participants at the 2005 AREUEA Meetings, the 2005 Homer Hoyt Institute, and the 2005 Pacific Rim Real Estate Society Meetings for comments, and to Jerry Crute and Erik Kallberg for research assistance. All errors remain our own.
} 


\begin{abstract}
This study analyzes how three groups of market participants - insiders, analysts, and investors - revised their expected returns on New York Real Estate Investment Trusts (REITs) in response to the catastrophic events of September 11, 2001. The attack on the WTC represents a unique experimental setting to evaluate financial markets' reaction to external shocks for several reasons. First, unlike prior studies of market reactions, these events, of a totally unanticipated and unprecedented nature, could not have been built into the market's expectations and prices; hence, market participants had to learn something new rather than just revise their beliefs from past occurrences. Second, again unlike other studies, the impact of the terrorist attacks on REIT returns was ambiguous, since it was uncertain if the effect of reduced supply of office space in New York would outweigh the impact of the negative shocks to the local and national economy on its demand. Finally, the period of market closure that followed 9/11 gave these players ample opportunity to reassess their expectations. Our analysis reveals that, on the day when markets reopened, REITs with significant exposure to the New York area outperformed a broad REIT office index by $4.1 \%$. However, we find that, according to several metrics of real market behavior, this anticipated superior performance of New York office properties did not materialize. Consistent with notions of market efficiency, we find that insiders were the first to lower their expectations (99.9\% of their trades in REITs with New York exposure were sales in the month following 9/11), followed by analysts (the vast majority of them revised downward their expectations of NY REIT performance in the first weeks of November 2001), and finally market prices adjusted to reflect the underlying real market behavior; indeed, abnormal REIT returns had disappeared by mid November 2001.
\end{abstract}

JEL classification: G14; R33

Keywords: Abnormal Returns; Market Over-Reaction; Nonresidential Real Estate; REITs 


\section{Introduction}

A critical aspect of asset pricing is the degree to which current prices accurately reflect informed investors' expectations of future cash flows. This topic has been the subject of a voluminous and diverse literature. Cowles (1933) began this debate by raising the issue of how well market participants react to information, initiating the vast literature addressing market efficiency. ${ }^{1}$ Another important starting point in the analysis of stock market reactions to news is in the early behavioral economics research. An example is Kahneman and Tversky (1973), who suggested that individuals have a tendency to overweigh recent news. ${ }^{2}$ Numerous studies have documented market overreaction. ${ }^{3}$ Other studies find under-reaction. ${ }^{4}$ In addition, researchers have documented that markets appear to be "too volatile," in the sense that prices move much more than the levels justified by changes in "fundamentals." 5

Our study builds on this research by empirically examining how three separate classes of market participants - insiders, analysts, and investors revised their expectations of returns on New York Real Estate Investment Trusts (REITs) in response to the catastrophic events of September 11, 2001. To allow our empirical analysis to be focused and tractable, we study the market presumably most affected: The metropolitan New York office real estate market. The attacks of 9/11 were unprecedented. Besides the horrific loss of human life, the devastation was immense. As of December 21, 2001, it was estimated that 13.4 million square feet of office space was destroyed, 12.1 million was damaged and remained closed, and only 5.6 million was damaged but could be re-opened. ${ }^{6}$

\footnotetext{
${ }^{1}$ See also Fama et al. (1969), Jegadeesh (1990), and Jegadeesh and Titman (1995), as well as Fama $(1991,1998)$ and Schwert (2003) for relatively recent surveys of market efficiency.

${ }^{2}$ In particular, a number of studies have examined how bad news concerning a bank's clients can affect the price of bank stocks; see, for example, Smirlock and Kaufold (1987) or Sinkey and Carter (1999).

${ }^{3}$ DeBondt and Thaler $(1985,1987)$ address the link between mean reversion and investor over-reaction, showing that portfolios formed from poor performers had significantly higher abnormal returns than portfolios formed from good performers. The latter paper focuses on the impact of time varying risk premia. DeBondt and Thaler (1990) provides evidence of overreaction in analysts' forecasts. This paper builds on the earlier analysis of Elton et al. (1984), who show that analysts over (under) estimate the growth in earnings of firms they believe would be good (bad) performers. More recently, Chan (2003) shows that bad news leads to significantly longer drift in prices than good news. See also Barrett et al. (1987), Lamb (1995), Veronesi (1999), and Carter and Simkins (2002).

${ }^{4}$ Cohen et al. (2002) is a recent example.

${ }^{5}$ See Shiller $(1981,1989)$ for an introduction to this topic.

${ }^{6}$ See Grubb and Ellis (2001).
} 
This event provides a unique setting to evaluate the speed and accuracy of belief revisions of insiders, analysts, and investors following external shocks. Indeed, unlike almost all studies of important economic events, this tragedy was certainly unanticipated and thus could not have been built into pre-existing market expectations and prices. Furthermore, the longest-ever period of market closure that followed the attack (from Tuesday, September 11 to the following Monday, September 17) gave investors ample time to digest the relevant information and to incorporate it into the prices that emerged when markets re-opened. ${ }^{7}$ Hence, our experiment is free from shortterm "behavioral" effects. Another unique aspect of our study is that, unlike other analyses of reactions to news, the short- and long-term impact of 9/11 on the New York office market was ambiguous. From the supply side, one could reasonably have assumed that the destruction of a vast amount of prime office space would drive up the value of the remaining New York office properties. $^{8}$ We call this argument the supply reduction effect. Conversely, one could have presumed that the resulting shocks to an already teetering economy would have plunged the city of New York and the nation into a deep recession, negatively affecting the price of real estate (and other) assets. We call this argument the recessionary shock effect. ${ }^{9}$ Finally, our data set, by allowing us to compare the real and financial market performance of office Real Estate Investment Trusts (REITs) with some New York exposure to those without any New York presence, also enables us to separate the local effects from the shocks that affected the entire U.S. office real estate market.

The main hypothesis we test in this study is whether or not the speed with which those three categories of market participants (insiders, analysts, and investors) adjusted to the true underlying behavior of the real markets is consistent with our usual notions of market efficiency. Each of these groups had a different information set and, presumably, based on the events on and following September 11, adjusted their beliefs about returns in different ways. Specifically, did insiders react faster than analysts, who in turn acted more quickly than the general class of investors? Our measurement of this speed of revision is necessarily indirect. We evaluate insiders' beliefs by their relative levels of selling and buying of REITs. We evaluate analysts' beliefs by their recommendations on REITs. Lastly, we evaluate the aggregate market's

\footnotetext{
${ }^{7}$ French and Roll (1986) provide an analysis of volatility during periods of market closure.

${ }^{8}$ The New York office area is the largest office market in the U.S., representing approximately $9 \%$ of its total urban office space. At the time of the September 11 attacks, the office vacancy rate in New York was only 3\%.

${ }^{9}$ We document these conflicting stances in Section 4 by examining analysts' reports in the months following September 11.
} 
beliefs by measuring the stock price performance relative to a REIT index benchmark.

To this purpose, we analyze all public REITs that specialize in office properties, with the sole exception of the two office REITs that owned properties directly hit by the terrorist attack to downtown Manhattan. ${ }^{10}$ This allows us to assess the performance of the underlying office properties (i.e., the physical rather than the securitized assets) by the end of the last quarter of 2001. This horizon strikes a balance between being long enough for us to assess the economic impact of the event on the real markets, and being short enough so that unrelated factors do not contaminate our performance measurements. ${ }^{11}$ The resulting sample of 27 office REITs allows us to study market participants' expectations about the impact of September 11 on the remaining supply of New York office space, both in an absolute sense and in relation to other U.S. office properties. REITs provide an ideal structure for our empirical tests for a number of reasons: (i) because of the availability of data on REIT holdings, we can accurately estimate each REIT's exposure to the New York office market; (ii) detailed data on the performance of the underlying real asset markets are available; (iii) the performance of the office REITs with New York exposure can be benchmarked against office REITs without New York exposure to control for macro real estate market effects.

To briefly survey our results, we find evidence that each of our three groups of market participants behaved in a manner consistent with market efficiency. This finding is remarkable in light of the fact that, unlike most studies of market reactions, the event we examine was not only unprecedented in scale and scope but also completely unanticipated. Specifically, we show that the equity market initially anticipated that REITs with an exposure to the New York market would achieve significant gains relative to their benchmark, consistent with the supply reduction effect. REITs with exposure to the New York market experienced an average excess return of 4.1\% from the close on September 10 to the close on September 17 relative to a broad REIT index. In contrast, the subsequent performance in the real asset market for office properties appeared to have reflected the recessionary shock hypothesis. According to several measures of real asset performance, New York properties experienced either a significantly negative or no abnormal performance with respect to similar office properties in the U.S. over the three-month horizon following the terrorist attack. Yet, we also find that

\footnotetext{
${ }^{10}$ These REITs are Brookfield Properties and TriZecHahn Corporation.

${ }^{11}$ Indeed, the impact on properties in the damaged areas involved highly complex insurance claims that were far from being resolved in the first three months after 9/11. The impact of September 11 on insurers is analyzed in depth by Doherty et al. (2003), who test the validity of several theoretical insurance models of external shocks.
} 
the divergence between the equity market's assessment of the impact of the events of $9 / 11$ on New York REITs and the corresponding resolution in the real markets quickly disappeared: The cumulative abnormal returns on New York REITs drifted to zero by early November.

New York REIT insiders were the first to accurately identify these developments. For the first eight months of 2001, insider trading patterns were almost identical for REITs with and without New York exposure. However, in the trimester after September 11, insider sales significantly exceeded insider purchases for REITs with New York exposure, while the reverse was true for non-New York REITs. For instance, in the month following the reopening of U.S. financial markets, insider trading in REITs with New York exposure was 26 times insider trading in REITs of comparable total market capitalizations but without New York exposure; in addition, sales represented $99.9 \%$ of the total volume of insider trades in New York REITs, but just $68 \%$ of the total volume of insider trades in REITs with no New York properties. This divergence suggests that insiders of New York REITs used their information to increase the frequency of their selling activity, in anticipation of the subsequent negative performance of the real market. Analysts followed this trend, albeit with a delay. Indeed, all the financial reports that we found issued in the ten days following $9 / 11$ indicated that REIT analysts initially expected New York REITs to benefit from the reduction in supply. However, just one quarter later, the same analysts began to emphasize the fact that the anticipated increased Manhattan demand was being efficiently absorbed and lowered their price forecasts for New York REITs.

The organization of the paper is as follows. Section 2 describes the relevant REIT data set; a discussion of the key aspects of the institutional structure of these securitized assets is in the Appendix. Section 3 presents and analyzes our empirical results. Section 4 investigates the significance of several alternative explanations for the REITs' reaction to the events of September 11. Section 5 concludes.

\section{Data Description}

We construct our REIT sample from the SNL REIT database. ${ }^{12}$ We use SNL's classification to obtain all REITs having an office property orientation (29 REITs), but exclude those with any exposure to downtown Manhattan (Brookfield Properties and TriZecHahn Corporation). This leaves a sample of 27 REITs, which we use in the analysis that follows. Since SNL also re-

\footnotetext{
${ }^{12}$ SNL Financial is the premier financial information provider for in-depth coverage of the real estate sectors.
} 
ports the location and square feet ${ }^{13}$ of each property in a REIT's portfolio, we segment our sample of office REITs into those having a New York City or New York metropolitan area exposure and those that do not. We define the New York metropolitan area as New York City (excluding downtown Manhattan), the outer boroughs (Brooklyn, Queens, Staten Island, The Bronx), Long Island (including Nassau and Suffolk), Westchester (including Rockland County), Southern Connecticut (including Fairfield, Hartford, and New Haven counties), and Northern New Jersey (including the following counties: Bergen, Essex, Hudson, Morris, Passaic, Sussex, Union, and Warren). For each office REIT in our sample, we calculated the total square feet for its office properties in New York City, and also in the New York metropolitan area. We scaled these figures by dividing each by the total square feet of office space in the entire REIT portfolio. This yields the percentage of an office REIT's square footage that is in New York City (PctNYC) and the percentage of an office REIT's square footage that is in the New York metropolitan Area (PctNYMetro).

We obtained close-to-close daily REIT returns from CRSP, the threemonth Treasury Bill rate from the Federal Reserve, ${ }^{14}$ and the daily return on the Morgan Stanley REIT Index (MSREIT), a capitalization-weighted benchmark index of the most actively traded REITs, over the interval 01/02/199809/17/2001 from Bloomberg. Opening and closing daily prices for REITs as well as the Dow Jones Industrial Average and the S\&P500 from the close on Monday, September 10, 2001 to the open and close of Monday, September 17, 2001 are obtained from the website http://finance.yahoo.com.

To assess the performance of the real markets we use the two most important valuation parameters in the real estate literature, the cap rate (i.e., the reciprocal of the EBITDA multiple) and the Net Asset Value (NAV). Liu and Mei (1992) show that the real market, as proxied by the cap rate, can predict equity REIT returns. Mei and Lee (1994) further find that the real estate premium found in Liu and Mei (1992) captures the systematic risk in the real estate market rather than real estate market imperfections. Damodaran and Liu (1993) find that NAVs contain information, by showing that insiders buy (sell) after they receive favorable (unfavorable) NAV news, especially for negative appraisals. Finally, Gentry et al. (2004) reveal that investors can profit from the deviations of REIT stock prices from their NAVs; using REIT data since 1990, they find large positive excess returns result from buying stocks trading at a discount to NAV, and shorting stocks

\footnotetext{
${ }^{13}$ The square footage is reported for most properties except those that are raw land and those that are in the process of being developed (construction in progress).

${ }^{14} \mathrm{Http}: / /$ www.federalreserve.gov/releases/\#daily.
} 
trading at a premium to NAV. The authors also find that the average price to NAV ratio is mean reverting toward one, implying that the aggregate price to NAV ratio can be used to predict aggregate REIT returns. NAVs and cap rates are also important tools for Wall Street REIT analysts. For example, according to A. G. Edwards (2000), “... a NAV analysis provides practical observations about the real estate value of a REIT relative to its public market valuation. A NAV analysis is also helpful on a relative basis in making decisions regarding the allocation of capital between direct real estate and real estate in the REIT format."

In this study, we take quarterly cap rates on real estate for New York and the nation, starting from the second quarter of 1994, from three sources:

1. The American Council of Life Insurance (ACLI) publication Investment Bulletin: Mortgage Commitments on Multifamily and Nonresidential Properties reported by 20 life insurance companies;

2. The National Real Estate Index (NREI) Market Monitor;

3. Korpacz Real Estate Investor Survey published by Price Waterhouse Coopers (PWC). ${ }^{15}$

As previously suggested, we compute the cap rate for each REIT as the ratio between its EBITDA and firm value on its direct real estate investment. ${ }^{16}$ The inverse of the cap rate, known as the EBITDA multiple, is a

\footnotetext{
${ }^{15}$ The three sources of data differ. The Korpacz Real Estate Investor Survey consists of quarterly survey results from major institutional equity real estate market participants. Those surveyed provide their expectations for returns on investments in institutionalgrade, real property. These expectations do not necessarily reflect the actual performance of such property. In contrast, NREI reports actual transactions of large income-producing properties and includes the transactions of REITs and real estate operating companies. The index attempts to keep quality constant by tracking only commercial real estate transactions that meet pre-specified property characteristics. The ACLI also reports actual transactions of institutional grade real property made by 20 life insurance companies. The ACLI data differs from that of NREI in that no attempt is made to keep the quality constant.

${ }^{16}$ Real estate practitioners define the cap rate as the ratio of "net stabilized" operating income (NOI) to the transaction price (or market value) of a property. "Net stabilized" means that the income figure used in the numerator assumes that full lease up of the building has occurred such that the building's vacancy is equal to or less than the vacancy of the market. Operating income is the difference between total rental revenue from properties and the corresponding property operating costs. The SNL REIT database reports property income and expenses in addition to REIT (firm) income and expenses.
} 
very familiar valuation metric in finance. ${ }^{17}$ To value the property portfolio of a REIT, we employ the cap rate valuation model commonly used by real estate appraisers. A real estate appraiser first calculates the average cap rate for comparable properties. Next, he/she multiplies the reciprocal of the cap rate by the EBITDA of the appraised property (called the stabilized net operating income) to obtain an estimate of the property value. Finally, the mortgage amount is subtracted from the resulting value of the property to obtain the value of the equity.

We also use the quarterly cap rates in conjunction with EBITDA for each REIT taken from the SNL REIT database to calculate the NAV per share for each REIT. ${ }^{18}$ Each REIT's NAV is computed as the ratio between its trailing twelve-month EBITDA and its blended cap rate. Individual blend cap rates are weighted averages of either actual (from NREI and ACLI) or expectational (from PWC) cap rates for both New York and the U.S., with weights given by the REIT's exposure to the NY metropolitan area (again excluding downtown Manhattan). NAVs per share are computed to control for the possibility that the REITs added properties to their portfolios and financed the purchase with a secondary stock offering. In the next section, we compute the time series of internal rates of returns (IRRs) for each of the REITs in our sample as the percentage quarterly change in these NAVs to measure the actual performance of their underlying real assets following the events of September 11.

\section{Empirical Results}

\subsection{Results from the Financial Markets}

Table 1 presents the basic characteristics of the 27 REITs in our sample as of September 1, 2001. Each REIT was mainly involved in office properties, although three REITs with substantial holdings in the New York metropolitan area (Forest City Enterprises, Lexington, and Voronado) were more diversified. Our analysis will focus on the group of 12 that had significant exposure to New York office properties (except downtown Manhattan, by construc-

\footnotetext{
${ }^{17}$ For example, in valuing the equity of a given firm a financial analyst using a relative valuation methodology will compute the EBITDA multiple for a set of comparable firms. The average of these multiples will be multiplied by the EBITDA for the subject firm to estimate its enterprise value. Finally, the value of the firm's debt is subtracted from the estimated total firm value to impute the equity value.

${ }^{18}$ When these data were missing from the SNL REIT database, we obtained them from the REITs' 10Q forms.
} 
tion); we dub this group the New York REIT group. ${ }^{19}$ Of our New York REIT sample, three had over half of their total holdings in the New York area: SL Green (100\%), Reckson Associates (93\%) and Mack-Cali Realty (62\%). The remaining 15 had no investment in the New York area. They represent a control sample in order to capture the more general effects of the event on the overall real estate market; we call this subset the national group.

Table 2 documents the stock market behavior of these REITs over the period from the close of the market on Monday September 10 to the open (column 2) and close (column 3) on Monday September 17, the first trading day after September 11. It is important to test the price behavior both at the opening, which incorporates the information over the period of the market closure, and, as a robustness check, at the close of the first trading day as well. The latter in fact captures the impact of any new information on the stock market's reaction to the crisis and is unaffected by distortions that can occur in opening prices. Panel A gives the unadjusted percentage change. The New York group gained an average of $1.998 \%$ to the open, but gave almost all of it back over the course of the trading day to close at a small average gain of $0.390 \%$. Conversely, the national group opened $2.075 \%$ lower and then lost a further $1.291 \%$ to close at a loss of $3.366 \%$. In both of these cases the New York average is significantly greater than the national average at the $5 \%$ level. This indicates that the market believed that the entire real estate sector would suffer because of the event, but that (presumably because of the supply reduction effect) New York office REITs would appreciate in value. Similarly, based on the standard deviation of returns, the dispersion of opinion was significantly higher (at least at the $10 \%$ level) for the New York group. The standard deviations at the open and close are in fact $5.683 \%$ and $3.493 \%$ for the New York group versus $1.676 \%$ and $2.344 \%$ for the national group. Panel B performs the same calculations with New York REIT returns relative to the Dow Jones 30 Index, which opened $6.798 \%$ lower than on September 10 and lost another 1.32\% during the day. The New York group now shows a relative gain of $8.796 \%$ to the open and $8.509 \%$ to the close.

Table 3 presents the cross-sectional correlations of the REIT groups. It shows that the correlation between the price change (close-to-open) and the percentage of property held in the New York area (excluding downtown Manhattan) is 0.781. The same correlation versus just New York City is 0.600. This suggests that the shock to supply is a strong factor in the market's revised value estimates. Figure 1 clarifies this correlation analysis. Figure

\footnotetext{
${ }^{19}$ In our subsequent analysis, we adjust for the relative proportions of properties within and outside the New York area in each of these REITs.
} 
1a plots the percentage price change (close-to-open) versus the amount of square footage in the New York metropolitan area. The positive slope is obvious, as is the clustering of negative returns for REITs with zero New York exposure. Figure 1b, which plots the same price change versus a REIT's percentage exposure to the New York metropolitan area presents a similar picture. Again the slope is positive and REITs with zero New York exposure have negative returns.

In Table 4 we estimate the (excess, if any) REIT market reaction to the events of September 11. We use the following return generating process to compute "normal" and "abnormal" returns: ${ }^{20}$

$$
r_{i t}^{C C}-r_{F t}=\alpha_{i}+\beta_{i}\left(r_{M t}-r_{F t}\right)+\varepsilon_{i t},
$$

where $r_{i t}^{C C}$ is the return on REIT $i$ from the close on day $t-1$ to the close on day $t, r_{F t}$ is the yield on the 90-day Treasury bill on day $t$, and $r_{M t}$ is the return on day $t$ on the Morgan Stanley REIT index. Eq. (1) is estimated over the interval January 2, 1998 - September 10, 2001 for each of the REITs in the sample. We then use those coefficients to compute normal (i.e., benchmark) close-to-close REIT returns $\widehat{r}_{i T^{*}}^{C C}$ on day $T^{*}=$ September 17, 2001, i.e., from the close on September 10 to the close on September 17. The resulting $R^{2}$ s are quite high for daily data, averaging about $21 \%$. The average estimates of $\alpha_{i}$ and $\beta_{i}$ in Eq. (1) are -0.0002 and 0.925 , respectively, indicating satisfactory performance of the benchmark. The national group showed no abnormal returns as well: Each of the estimated $\alpha_{i} \mathrm{~s}$ is in fact statistically insignificant.

According to Table 4, REITs with exposure to the New York metropolitan area out-performed the overall U.S. real estate market by a statistically significant $4.1 \%$ on average: $r_{i T^{*}}^{C C}-\widehat{r}_{i T^{*}}^{C C}=0.041$ in row NY of Table 4 . The superior performance of the New York REIT group was even more pronounced at the opening of trading. Normal close-to-close New York REIT returns $\widehat{r}_{i T^{*}}^{C C}$ from Eq. (1) are estimated to be about $5.7 \%$ lower than the corresponding return from the close on September 10 to the open on September 17, $r_{i t}^{C O}$. Furthermore, estimated abnormal returns are the greatest for REITs for which close-to-open returns $r_{i T^{*}}^{C O}$ are positive on September 17; $88 \%$ of those REITs had office properties in New York.

\footnotetext{
${ }^{20}$ Kallberg et al. (2000) show that a one-factor return generating process with a REIT index as the factor performs as well as more complex models (e.g., using Fama-French and other factors).
} 


\subsection{Results from the Real Markets}

The above evidence suggests that the REIT equity markets anticipated that the supply reduction effect would dominate the recessionary shock effect and thus moved the prices of REITs with New York exposure significantly higher than REITs without New York exposure. We now turn our attention to the actual performance of the underlying real assets over the three months that followed the event. This interval was chosen in order to have enough time for the key uncertainty surrounding the crisis to be resolved, but short enough so that other exogenous factors do not begin to play an important role in real asset returns.

Based on the observations in Section 2, we use a variety of measures of real market performance based on expectational and realized data in order to present a robust analysis. In particular, we focus on different measures of quarterly internal rates of return (IRRs) for each of the REITs in the sample. We define REIT $i$ 's IRR in quarter $\tau$,, $\operatorname{irr}_{i \tau}$, as the percentage change in its NAV over that period. Then, we compare those IRRs to benchmark IRRs given by weighted averages of New York and national real rates of return. Specifically, we compute excess IRRs in three steps. First, we compute "normal" quarterly real rates of return for NY office REITs estimating the following regression over the time period 1994.Q2 to 2001.Q2 (29 observations):

$$
i r r_{\tau}^{N Y}-r_{F \tau}=\alpha+\beta\left(r_{U S \tau}-r_{F \tau}\right)+\eta_{\tau},
$$

which mimics Eq. (1) using rates of return from real rather than financial markets. Here $i r r_{\tau}^{N Y}$ is the estimated rate of return on our New York sample, $r_{F \tau}$ is the yield on the 90-day Treasury bill over quarter $\tau$, and $r_{U S \tau}$ is the nation-wide real estate IRR in quarter $\tau$ from the Korpacz Data Index, which is constructed with a variety of measures of real market performance (see Section 2). Second, the resulting estimated coefficients $\widehat{\alpha}=0.003$ and $\widehat{\beta}=$ 0.831, are used to compute "normal" NY REIT returns, $\widehat{i r r}_{\tau^{*}}^{N Y}=i r r_{\tau^{*}}^{N Y}-\widehat{\eta}_{\tau^{*}}$ for $\tau^{*}=2001 . \mathrm{Q} 4$, to control for the impact of the idiosyncratic events of September 11 on the NY office business. The $R^{2}$ of $83 \%$ indicates that Eq. (2) does an excellent job of describing NY REITs' real returns. Finally, excess IRR for each REIT in quarter $\tau^{*}=2001$.Q4 is computed as the difference between its quarterly IRR, $i r r_{i \tau^{*}}$, and the corresponding benchmark $i r r_{i \tau^{*}}^{B}=$ $\omega_{i} \widehat{i r r} \tau_{\tau^{*}}^{N Y}+\left(1-\omega_{1}\right) r_{U S \tau^{*}}$, where $\omega_{i}$ is the percentage of the REIT $i$ 's office space in the NY metro area reported in Table 1.

Table 5a reports estimated excess IRRs measured using the percentage quarterly change in Net Asset Value (NAV) for each REIT in the sample 
computed using three different blend (i.e., weighted) cap rates: The NREI data in columns 3 and 4, the ACLI data in columns 5 and 6 , and the expectational data from PWC in columns 7 and 8 (see Section 2). The most striking result is the difference between the ensuing average abnormal real returns and the estimated excess REIT returns in Table 4. Table 5a shows in fact that the real abnormal returns to the New York REITs over the quarter immediately following $9 / 11$ were either statistically significantly negative (at the $2 \%$ level) or zero, in contrast to their positive relative performance in the financial markets over the period of market closure $(4.1 \%$ in Table 4). More specifically, the sample average abnormal real returns for NY REITs, $i r r_{i \tau^{*}}-i r r_{i \tau^{*}}^{B}$, based on each of the three measures above, were $-3.3 \%$, $0.4 \%$, and $-3.0 \%$ (with $t$-statistics of $-2.80,0.30$, and -2.83 ), respectively. In addition, although the real market performance of the national group was somewhat lower, according to each of our three metrics, the differences between the two groups were never statistically significant. Yet, this comparison is somewhat inappropriate because of the different benchmarks used to compute abnormal performance in the two groups. Similarly, REITs that increased in price from close-to-close out-performed those that lost by $3.3 \%$, $3.6 \%$, and $1.1 \%$, respectively, while REITs that had positive returns at the open on September 17, $2001\left(r_{i T^{*}}^{C O} \geq 0\right)$ out-performed those REITs with negative returns at the open $\left(r_{i T^{*}}^{C O}<0\right)$ in two of the three cases (using NREI and ACLI measures). Yet again none of these differences was statistically significant.

Table 5b reports the same analysis when NAVs are calculated with only U.S. cap rates, to ensure that our results are not driven by the procedure used to compute blend cap rates. The results parallel those obtained in Table 5a. The under-performance of the New York group is now more pronounced, and significantly negative, for each of the three measures. When comparing those negative excess real return across subsets of our sample, we again find that the New York group out-performed the national group, although now the differences are much smaller: About 1.0\% using either NREI, ACLI, or PWC data. However, REITs that gained or lost during the first trading day had virtually identical performance. Moreover, none of these differences is statistically significant, as in Table 5a. We obtained similar results (not reported here) by computing REIT IRRs from changes in their Net Equity Values (NEV), equal to their NAVs minus Debt.

Finally, we further investigate the real performance of the New York office market by computing four additional measures of real estate market dynamics commonly used by practitioners: The nominal rent index, the going-in cap rates, the expectational IRR, and the NEVs defined above. We find that i) the nominal rent index for New York declined by $4.6 \%$ (versus an 
average of $2.6 \%$ for the rest of the U.S.) ${ }^{21}$ ii) the in-going cap rates for New York actually increased by $10.1 \%$, yet less so than the average of $10.6 \%$ for markets outside New York, ${ }^{22}$ iii) expectational IRRs for New York increased by 33 basis points versus an average decrease of 18 basis points for the rest of the U.S.; ${ }^{23} \mathrm{iv)} \mathrm{NEVs} \mathrm{for} \mathrm{the} \mathrm{first} \mathrm{nine} \mathrm{months} \mathrm{following} \mathrm{9/11} \mathrm{were} \mathrm{not}$ significantly different across the REITs with or without New York exposure in our sample. Overall, this evidence, although somewhat mixed, on balance corroborates our earlier analysis of excess IRRs: The real performance of New York REITs was either weaker than or not statistically different from that of REITs with no such exposure.

\section{Analyzing the Adjustments to Real Market Conditions}

Our analysis suggests that, while New York REITs experienced significantly positive abnormal stock market returns from the close on September 10 to the close on September 17, 2001, this superior performance did not materialize in the real asset markets. Specifically, in the quarter following September 11, the real asset markets in New York significantly under-performed relative to their benchmarks, regardless of the measure of real asset performance employed. Armed with these results, we now turn to the major issue raised in this study: How quickly did each of the three groups of market participants we consider, insiders, analysts, and REIT equity investors, adjust to the real market conditions? To address this issue, we first examine the trading behavior of insiders in the months before and after 9/11. Secondly, we investigate the recommendations of REIT analysts around the event. Finally, we examine the abnormal returns on New York REITs in the months subsequent to the World Trade Center (WTC) attacks. As noted earlier, market efficiency would imply that insiders (because of their superior information set) should react first, followed by analysts (because of their superior access to insiders' information) and, lastly, the revised expectations of the overall market should reduce REIT abnormal returns.

\subsection{REIT Insiders}

Figure 2 performs the first of these tests. It shows the cumulative sums of scaled differences between total insider purchases and sales in REITs with

\footnotetext{
${ }^{21}$ Source: Torto-Wheaton.

${ }^{22}$ Source: American Council of Life Insurance (ACLI).

${ }^{23}$ Source: Price Waterhouse Coopers (Korpacz).
} 
(solid line) or without (dashed line) exposure to the New York metropolitan area (excluding downtown Manhattan) that are sales. The data are obtained from WRDS (Wharton Research Data Services) TFN Insider Filing Data Files. ${ }^{24}$ If insiders correctly believed that the prices of REITs with New York exposure would decline relative to their peers, then we should see a relatively higher amount of selling by the insiders of New York REITs following the terrorist attack to downtown Manhattan.

Figure 2 shows that, for the first seven months of 2001, the two cumulative ratios were almost identical for REITs with and without New York exposure. Indeed, the average percentage of sales was approximately $46 \%$ of all trades for both groups. However, in the first three months after September 11, insider sales exceeded insider purchases for REITs with New York exposure, hence the corresponding ratio trended downward and turns negative, while the ratio for the national group continued to trend upward. This divergence in selling and buying patterns suggests that insiders of the New York group used their information to increase the frequency of their selling activity.

The analysis of each of the trades reported by REIT insiders offers further evidence on the nature of their trading activity after September 11. In particular, we focus on the first month following the terrorist attack. Over this sample period, the total amount of trading by insiders of REITs not exposed to the New York area was relatively small, totaling only $\$ 0.9$ million. Of these trades, $68 \%$ were sales; yet a single one, executed on September 17,2001 , dominated that balance, amounting to $\$ 0.57$ million. In contrast, trades by insiders of the New York group totaled $\$ 23.4$ million. Of this total, about $99.9 \%$ were sales. These observations confirm our earlier finding of significantly higher selling by New York REIT insiders immediately after 9/11, and are consistent with the notion that insiders believed the U.S. stock market had temporarily overvalued those securities relative to other office REITs.

\subsection{REIT Analysts' Reports}

The second part of our analysis focuses on the behavior of REIT analysts following the events of September 11. We searched Investext for analyst reports regarding the impact of the WTC attacks on REITs issued around the

\footnotetext{
${ }^{24}$ This database, available at http://wrds.wharton.upenn.edu, contains all insider activity as reported on SEC forms 3, 4, 5, and 144. According to the WRDS documentation, "Corporate insiders are defined broadly to include those that have 'access to non-public, material, insider information' and these insiders are required to file SEC form 3, 4, and 5 when they trade in their companies stock." We were unable to compute dollar amounts for these trades because, in many cases, the actual transaction prices were not reported.
} 
time of the attack. ${ }^{25}$ As a specific illustration, we focus on analysts' reports for Mack-Cali (CLI), the NY REIT followed by the largest number of analysts in our sample. ${ }^{26}$ On August 16th, 2001 Morgan Stanley issued a note maintaining its position that Mack Cali was expected to "under perform" (even though they beat analyst estimates) based on erosion in market fundamentals and on the expected acceleration of their disposition program, which was expected to dilute earnings. ${ }^{27}$ This negative opinion was partly based on management lowering expected 2001 earnings to reflect potential occupancy erosion in their portfolio, the sustainability of rental rates, and the timing of the company's ongoing capital recycling program. Prior to 9/11, REIT analysts from other investment banks held a similar opinion about the New York market and Mack-Cali in particular as Table 6 shows.

All the reports that we found issued in the ten days following $9 / 11$ indicated that REIT analysts expected New York area REITs to benefit from the anticipated scramble for space in both Midtown and in NJ, CT, Long Island, and Westchester based on an expected tightening of office market space in the short run. For example, from Axelrod (2001), "The taking out of 25 million square feet of Manhattan office space has dramatically tightened the entire NYC metro office market which stood at $7.5 \%$ vacancy (direct and sublease, Manhattan only) at the end of Q201. However, for the rest of the national office markets, a recession is a decided negative." Given this anticipated reduction in supply, analysts raised their target price for REITs having a New York presence. From Raiman et al. (2001), “... in response to shrinkage of office supply in Manhattan - and its positive implication on the tri-state market, we are raising our target price to $\$ 34-\$ 35$ on Mack-Cali Realty given its office concentration in the Tri-State area."

However, analysts just one quarter later emphasized the fact that the anticipated occupancy pressure was not offset with increased Manhattan demand. As noted in Litt (2001), "The vast amount of 'phantom vacancy' that appeared in Manhattan following the attack will likely limit some of the upside we expected in Mack-Cali's 2002 occupancy as many displaced tenants have found space in Manhattan." Taylor (2001) agreed, stating that "... the WTC impact was short lived ... tenants in midtown New York have been

\footnotetext{
${ }^{25}$ Investext is currently the world's largest online database of company and industry investment research reports. These reports are not generally available through public channels.

${ }^{26}$ In addition, Mack-Cali had a sizable presence in the New York metropolitan area as of September 1, 2001 (about $62 \%$ of its office properties, based on square footage, according to Table 1).

${ }^{27}$ This report, Whyte (2001), was the last analyst report issued on Mack-Cali prior to the attack on the World Trade Center.
} 
rethinking their space needs and giving up space. This has relaxed the tightness in the NYC market that had driven demand to Harborside (in Jersey City, NJ). Like most investors and analysts, we thought there'd be a benefit from the loss of space in Manhattan. We thought it would be short term, but not this short." Finally, Paolone (2001) noted in a report made available on November 7, 2001 that "At this point, much of the scramble for space is over as a result of September 11th and the bigger impact is on the negative side as demand wanes." As shown in Table 6, Morgan Stanley, Lehman Brothers, Banc of America, and Salomon Smith Barney all initially raised their earnings estimates immediately following $9 / 11$, but then all lowered those estimates between November 8 and 12, 2001. Deutsche Banc issued no updates to its August 10 earnings forecasts in response to the terrorist attack until it confirmed them on November 8, only to reduce its 2002 earnings estimates the following day. CS First Boston issued a strong buy on September 18, 2001 but released no further report until May of 2002. The timing and content of analysts' recommendations on the other NY REITs in our sample over that period provide a strikingly similar picture. For instance, of the analysts that published earnings estimates for REITs with NY exposure both in the two weeks following 9/11 and in either October or the first two weeks of November, downgrades out-numbered upgrades by more than three to one. These reports collectively suggest that analysts reversed their initial positive outlook approximately two months after $9 / 11$.

\subsection{The Aggregate Market}

Lastly, we examine the abnormal returns on New York REITs in the weeks and months immediately following 9/11. Indeed, if the relative values of New York REITs were actually declining, we would expect to see all market participants eventually revise their initial expectations rationally, hence the positive abnormal returns registered on September 17, 2001 (reported in Table 4) eventually decline (towards zero) as well. This third test is performed in Figure 3, which plots cumulative abnormal returns (CARs, solid line) for the REITs with NY exposure listed in Table 1 over the nine-month sample period from September 17, 2001 to June 17, 2002. We also plot a $95 \%$ confidence interval (dashed lines) under the null hypothesis of no cumulative excess returns. CARs are generated by first computing close-to-close abnormal returns (ARs) estimated using the market model of Eq. (1) over the interval January 2, 1998 - September 10, 2001 (in Table 4) and then aggregating them over time and across REITs.

CARs are initially highly positive and significant, as a result of the relatively superior performance of this group immediately after September 11. 
However, the solid line drifts quickly downward, crossing the upper bound of the confidence interval in early November before reaching zero immediately afterwards. In the following seven months, the CARs remain relatively small and almost always statistically indistinguishable from zero. Hence, Figure 3 shows that although the markets initially expected that 9/11 would have a positive impact on New York REITs, REIT prices quickly reflected the underlying behavior of the real markets. Interestingly, the sharp decline in abnormal returns exhibited in Figure 3 begins on November 7 and lasts until November 19, i.e., around the time analysts started revising downward their EPS forecasts for NY REITs (e.g., the sequence of downgrades for Mack-Cali between November 8 and 12, 2001 in Table 6). This is consistent with the notion that financial markets eventually reacted to negative analysts' reports on those REITs' future earnings.

\subsection{Real Market Frictions}

While it is impossible to rigorously evaluate the possible reasons for those estimated differences in timing, sign, and/or magnitude of the reactions of real and financial markets, as well as of various groups of market participants, to the events of $9 / 11$, one issue is clear. Analysts and the financial markets initially anticipated that, in the New York metro area, the supply reduction effect would be sufficient to generate relatively superior returns to REITs with exposure to the New York office market. However, as we documented above, this superior performance did not materialize, at least not in the short run.

Real estate practitioners primarily attribute this disparity to two sources. In essence, these arguments involve the fact that employers laid off workers faster than they could layoff space. This factor, coupled with excess space known as "shadow" 28 space by New York metro area employers, resulted in

\footnotetext{
${ }^{28}$ The National Association of Realtors (NAR) defines shadow space as space that isn't being occupied by the tenant but isn't being actively marketed either. Shadow space is a difficult number to obtain. In an RCA (Realtors Commercial Alliance) Report dated Fall 2003, Torto Wheaton research estimated that nationwide, shadow space represents an additional $3 \%$ of unoccupied space that is not reflected in vacancy numbers. Mitchell Stein, CEO of Julien J. Studley Inc., a commercial leasing agent, stated in the same report that shadow space for Manhattan accounts for between 2.5\% to 3.5\% (10 to 14 million square feet) of unoccupied space. Shadow space exists not only because firms can lay off workers faster than they can lay off space but also because companies worry they won't be able to find space in the future and thus take more than they presently require. There are other reasons why space remains in the shadows. These reasons include the fact that very small amounts of space are difficult to lease as well as space with only one to two years remaining on a lease is unmarketable except to very flexible tenants. Also the cost
} 
a sufficient supply of space for displaced tenants. According to Grubb \& Ellis (2001), by December 2001, permanently displaced tenants contracted to take only $48 \%$ as much space as they had formerly occupied. In addition, since September 11, New York companies that were not directly effected reevaluated their space needs and offered an additional 10.1 million square feet of space available for sublet. Much of this additional sublet space came from Wall Street firms. Consequently, the amount of displaced tenants that were expected to lease new space somewhere in Manhattan was not as large as anticipated.

In addition to a reduction in the demand for space, corporations also downsized their workforce in the post 9-11 period. In New York City, the securities industry alone lost 9, 800 jobs; a total of 31,100 private sector jobs were lost in 2002, as the unemployment rate rose to $8.4 \%$. Besides an increase in vacancy, the anticipated increase in rents did not materialize in part due to the Real Estate Board of New York's (REBNY) written memo to its members that "Any member owner, firm, or broker found to be taking advantage of this terrible tragedy will be expelled from the Real Estate Board." ${ }^{29}$ While some critics might argue that expectations might not have been realized because tenants moved out of the New York metro area, Table 7 shows that only a small portion (5.4\%) of tenants relocated outside of the metro area. The overwhelming majority of displaced tenants $(84.9 \%)$ chose to remain in New York City.

Finally, we consider the possibility that the discrepancy between the relative performance of financial and real markets for the NY REITs in our sample following September 11 may be due, at least in part, to the arrival of idiosyncratic news affecting those REITs between September 10 and September 17,2001 . We check for this argument by examining all relevant information events taking place for each of the 27 REITs in our sample over that interval of time. The ensuing sequence of these events (from Lexis-Nexus), reported in Table 8, suggests that none of the REITs under examination experienced information shocks significant enough to bias our statistical analysis, i.e., to contribute to the abnormal returns estimated in Table 4.

to reconfigure the space to make it subleasable might not be justified.

${ }^{29}$ According to the information reported on the website http://www.propertymag.com/property/Winter02/coverstory_print.html, REBNY urged its members not to take advantage of displaced tenants when negotiating lease rates and suggested using rental rates in place prior to September 11. REBNY also asked brokers to waive their usual commissions and fees in assisting displaced tenants who required short-term (less than 12 months) leases. 


\section{Conclusions}

The ability of financial markets to process available information quickly and accurately is the cornerstone of modern theories of market efficiency. This study examined how three different groups of market participants - insiders, analysts, and the general market - revised their beliefs in response to a dramatic and unexpected event, the terrorist attacks on September 11, 2001, and how their reactions compared to the subsequent behavior of the real asset markets. To that end, we analyzed the dynamics of returns of REITs exposed to the New York metropolitan area. Two of the unique aspects of this study (as compared to the existing literature on economic shocks) are that (i) the events of September 11 were completely unprecedented and totally unanticipated, hence could not have been built into the market's prior expectations and prices, and (ii) the potential impact of those events on REIT returns was ambiguous, since it was uncertain if the resulting reduced supply of office space in New York (the supply reduction effect) would dominate the negative repercussions of 9/11 for the local and national economy (the recessionary shock effect). A further distinguishing feature of our study is that we focus on the speed with which these three groups of markets participants were able to incorporate the performance of the underlying real asset market into their expectations for REIT performance.

We found economically and statistically significant evidence of a divergence between financial and real markets' assessment of the impact of the events of September 11 on New York REITs' valuations. Indeed, returns on New York office REITs from the close on September 10 to the close on September 17 and returns in the underlying real markets over the following quarter moved in opposite directions. New York REITs showed a significantly positive abnormal return of $4.1 \%$, while the corresponding real markets over the last quarter of 2001 showed significantly negative abnormal returns for five of our six measures of real performance. In short, our analysis revealed that, in the short run, REITs with significant exposure to the New York market outperformed REITs without any New York exposure; in contrast, in the underlying real asset markets, New York properties experienced either significantly negative or no abnormal performance with respect to similar office properties in the U.S. over the first quarter following 9/11. These latter results also provide additional evidence on the resiliency of real product markets in response to catastrophic events. According to our analysis, the New York real estate market was in fact able to absorb an enormous shock without suffering huge price increases or severe shortages. This is consistent with the findings of Davis and Weinstein $(2002,2004)$ for post World War II Japan and other settings. 
Consistent with notions of market efficiency, we also found that insiders updated their expectations more accurately and faster than analysts, who in turn revised their expectations more accurately and faster than the aggregate market. Specifically, insiders were the first to lower their expectations consistently with the real market. For example, in the month following the re-opening of U.S. financial markets, insider trading in REITs with New York exposure was 26 times insider trading in REITs of comparable total market capitalizations but without New York exposure. Further, sales represented 99.9\% of the total volume of insider trades in New York REITs, but just $68 \%$ of the total volume of insider trades in REITs with no New York properties. Analysts were almost as quick to adjust their recommendations: After being initially optimistic about the New York office market, by early November most REIT analysts had lowered their EPS and stock price targets for New York REITs. Lastly, REIT stock prices adjusted to reflect the underlying real market behavior; indeed, abnormal REIT returns had disappeared by the end of November 2001. These findings are remarkable since they suggest that both financial and real markets responded efficiently to a massive, unprecedented, and wholly unexpected shock to the economy.

Finally, we investigated some plausible explanations for the differences in the behavior of real and financial markets following the events of $9 / 11$. In particular, we explored whether confounding news could have contributed to the run-up of REIT stock prices. Yet, we could not identify any significant idiosyncratic information shock taking place during the ensuing one-week market shut-down for any of the REITs in our sample. The weaker-thanexpected real performance of NY REITs appeared instead to be related to the ability of many downtown firms to reduce space requirements, after the forced relocation, and to lower-than-expected actual vacancy rates, as argued by real estate practitioners.

\section{Appendix: Institutional Features of REITs}

Congress created REITs in 1960 to provide individual investors a vehicle for owning income-producing real estate through pooling arrangements. The early REIT issues were viewed as passive diversification plays for individual investors but, as the market developed, they became alternatives to direct real estate investment for institutional investors.

It is important to our study to realize that the REIT structure make the analysis of their dynamics less difficult than for the typical equity. As detailed below, there are severe restrictions on dividend payout, which means that a REIT manager has much less discretionary cash flow than the manager of 
a normal corporation. In addition, the law restricts the types of activities in which a REIT can engage, thus limiting the manager's opportunities to fund negative NPV projects or projects that have significant private benefits. Finally, because the holdings of a REIT, mostly physical properties, are public knowledge, the informational asymmetry with respect to the average investor is also reduced. This is important when considering the implications of the WTC attacks on REIT's valuation.

A REIT is not taxed at the firm level if it satisfies the provisions outlined below. These regulations are designed to ensure that REITs, which hold a portfolio of properties and/or mortgages for the long term, will be passive investment vehicles similar in concept to open-ended mutual funds.

1. At least $95 \%$ of net annual taxable income is distributed to shareholders $;^{30}$

2. At least $75 \%$ of annual gross income comes from rents, mortgage interest, gains from selling real estate, and dividends from investing in other REITs;

3. At least $75 \%$ of all assets consists of real estate, mortgages on real estate, shares of other REITs, cash, or government securities;

4. At least $95 \%$ of the REIT's gross income comes from items qualifying under the $75 \%$ income test, dividends and interest income, and gains from the sale of stock and other securities;

5. At least 100 shareholders must exist with no more than 50 percent of the shares held by five or fewer shareholders;

6. It must elect to be treated as a REIT;

7. Real property must not be held primarily for sale in the ordinary course of business (gains from the sale of property held for less than four years must comprise less than $30 \%$ of gross income);

8. Trustees, directors or employees of a REIT are restricted from actively managing or operating REIT property, although they are permitted to make property decisions if such decisions relate to the business of the REIT itself.

\footnotetext{
${ }^{30}$ Recent regulatory changes (effective in the beginning of 2001) have changed this to $90 \%$ of taxable income.
} 
The REIT market has undergone numerous structural changes since its inception in 1960. REITs formed during the 1960s and 1970s were mostly engaged in higher-risk development and construction loans, and were illpositioned to withstand the real estate crash of the mid 1970s. REITs created in the 1980s were basically passive, diversified holdings of real estate. Most were finite-horizon REITs, which limited their growth potential. This market structure changed dramatically in the 1990s. The new REITs featured active management, low leverage, infinite lives and substantial insider holdings (often more than a third of the outstanding shares). These changes led to greater institutional ownership, as documented in Ling and Ryngaert (1997). For the pre-1990 REITs, institutional shareholders usually held less than $10 \%$ of the outstanding shares one quarter after the IPO. The corresponding figure for the post-1990 REITs is $42 \%$.

\section{References}

[1] Axelrod, S. (2001). Morning Meeting Note. Lehman Brothers, September 21, 2001.

[2] A.G. Edwards (2000). Equity Office Properties.

[3] Barrett, W., A. Heuson, R. Kolb, G. Schropp (1987). The Adjustment of Stock Prices to Completely Unanticipated Events. The Financial Review, 22, pp. 345-354.

[4] Carter, D., B. Simkins (2002). Do Markets React Rationally? The Effect of the September 11th Tragedy on Airline Stock Returns. Working paper, Oklahoma State University.

[5] Chan, W. (2003). Stock Price Reaction to News and No-News: Drift and Reversal After Headlines. Journal of Financial Economics, 70, pp. 223-260.

[6] Cohen, R., P. Gompers, T. Vuolteenaho (2002). Who Underreacts to Cash-Flow News? Evidence from Trading Between Individuals and Institutions. Journal of Financial Economics, 66, pp. 409-462.

[7] Cowles, A. (1933). Can Stock Market Forecasters Forecast? Econometrica, 1, pp. 309-324.

[8] Daniel, K., D. Hirschleifer, A. Subrahmanyam (1998). Investor Psychology and Security Market Under- and Over-Reactions. Journal of Finance, 53, pp. 1839-1885. 
[9] Damodaran, A., C. Liu (1993). Insider Trading as a Signal of Private Information. Review of Financial Studies, 6, pp. 79-120.

[10] Davis, D., D. Weinstein. (2002). Bones, Bombs, and Break Points: The Geography of Economic Activity. American Economic Review, 92, pp. 1269-1289.

[11] Davis, D., D. Weinstein. (2004). A Search for Multiple Equilibria in Urban Industrial Structure. NBER Working Paper No. 10252.

[12] DeBondt, W., R. Thaler (1985). Does the Stock Market Overreact? Journal of Finance, 40, pp. 793-805.

[13] DeBondt, W., R. Thaler (1987). Further Evidence on Investor Overreaction and Stock Market Seasonality. Journal of Finance, 42, pp. 557-581.

[14] DeBondt, W., R. Thaler (1990). Do Security Analysts Overreact? American Economic Review, 80, pp. 52-57.

[15] Doherty, N., J. Lamm-Tennant, L. Starks (2003). Insuring September 11th: Market Recovery and Transparency. The Journal of Risk and Uncertainty, 26, pp. 179-199.

[16] Elton, E., M. Gruber, M. Gultekin (1984). Professional Expectations: Accuracy and Diagnosis of Errors. Journal of Financial and Quantitative Analysis, 19, pp. 351-363.

[17] Fama, E. (1991). Efficient Markets II. Journal of Finance, 46, pp. 15751617.

[18] Fama, E. (1998). Market Efficiency, Long Term Returns and Behavioral Finance. Journal of Financial Economics, 49, pp. 283-306.

[19] Fama, E., L. Fisher, M. Jensen, R. Roll (1969). The Adjustment of Stock Prices to New Information. International Economic Review, 10, pp. 1-21.

[20] French, K., R. Roll (1986). Stock Return Variances: The Arrival of Information and the Reaction of Traders. Journal of Financial Economics, 17 , pp. 5-26.

[21] Garmaise, M., T. Moskowitz (2004). Confronting Information Asymmetries: Evidence for Real Estate Markets. Review of Financial Studies, 17, pp. 405-437. 
[22] Gentry, W., C. Jones, C. Mayer (2004). REIT Reversion: Stock Price Adjustments to Fundamental Value. Working Paper, Columbia University.

[23] Grubb and Ellis Research, 2001. NYC's Office Market - A Post 9-11 Update. December.

[24] Jegadeesh, N. (1990). Evidence of Predictable Behavior of Security Prices. Journal of Finance, 45, pp. 881-898.

[25] Jegadeesh, N., S. Titman (1995). Overreaction, Delayed Reaction, and Contrarian Profits. Review of Financial Studies, 8, pp. 973-993.

[26] Kahneman, D., A. Tversky (1973). On the Psychology of Prediction. Psychological Review, 80, pp. 237-251.

[27] Kallberg, J., C. Liu, C. Trzcinka (2000). The Value Added from Investment Managers: An Examination of Funds of REITs. Journal of Financial and Quantitative Analysis, 35, pp. 387-408.

[28] Lamb, R. (1995). An Exposure-Based Analysis of Property-Liability Insurer Stock Values around Hurricane Andrew. The Journal of Risk and Insurance, 62, pp. 111-123.

[29] Ling, C., M. Ryngaert (1997). Valuation Uncertainty, Institutional Involvement, and the under-pricing of IPOs: The Case of REITs. Journal of Financial Economics, 43, pp. 433 - 456.

[30] Litt, J. (2001). Mack-Cali (CLI): Occupancy Pressure Not Offset with Increased Manhattan Demand. Salomon Smith Barney, November 8, 2001.

[31] Liu, C., J. Mei (1992). The Predictability of Returns on Equity REITs and Their Co-Movement with Other Assets. Journal of Real Estate Finance and Economics, 5, pp. 401-418.

[32] Mei, J., A. Lee. (1994). Is There a Real Estate Factor Premium. Journal of Real Estate Finance and Economics, 9, pp. 113-26.

[33] National Association of Realtors, RCA (Realtors Commercial Alliance) Report, Volume 4, Issue 4, Fall 2003, p. 4.

[34] Paolone, A. (2001). Reckson Associates. CIBC World Markets, November 7 . 
[35] Raiman, L., Dembski, M., Habermann, J., Schwalbe, J. (2001). Morning Meeting Note. Credit Suisse First Boston, September 17, 2001.

[36] Schwert, G. W. (2003). Anomalies and Stock Market Efficiency. Handbook of the Economics of Finance, Volume 1B, G. Constantinides, M. Harris and R. Stulz editors, Elsevier Press, Amsterdam.

[37] Shiller, R. (1981). Do Stock Prices Move Too Much to Be Justified by Subsequent Changes in Dividends? American Economic Review, 75, pp. 421-436.

[38] Shiller, R.(1989). Market Volatility, MIT Press, Cambridge MA.

[39] Sinkey, J., D. Carter (1999). The Reaction of Bank Stock Prices to News of Derivatives Losses by Corporate Clients. Journal of Banking and Finance, 21, pp. 1725-1743.

[40] Smirlock, M., H. Kaufold (1987). Bank Foreign Lending, Mandatory Disclosure Rules and the Reaction of Bank Stock Prices to the Mexican Debt Crisis. Journal of Business, 60, pp. 347-364.

[41] Straetmans, S., W. Verschoor, C. Wolff (2003). Extreme U.S. Stock Market Fluctuations in the Wake of 9/11. Working Paper, Maastricht University.

[42] Taylor, L., T. Goebel (2001). CLI: WTC Impact Is Short-Lived. Deutsche Banc Alex Brown Inc., November 9, 2001.

[43] Veronesi, P. (1999). Stock Market Overreaction to Bad News in Good Times: A Rational Expectations Equilibrium Model. Review of Financial Studies, 12, pp. 975-1007.

[44] Whyte, G. (2001). Mack-Cali Realty: CLI; 2001 Guided Lower Despite 2Q01 Beat. Morgan Stanley, August 16, 2001. 


\section{Table 1. Sample REITs}

This table provides basic information for each of the 27 REITs included in our sample as of September 1, 2001. The column labeled NY indicates the percentage of office space (in square feet) in the NY metro area in the portfolio of the corresponding REIT. The NY metro area includes New York City (but not downtown Manhattan), the outer boroughs (Brooklyn, Queens, Staten Island, The Bronx), Long Island (including Nassau and Suffolk), Westchester (including Rockland County), Southern CT (including Fairfield, Hartford, and New Haven counties), and Northern NJ (including the following counties: Bergen, Essex, Hudson, Morris, Passaic, Sussex, Union, and Warren).

\begin{tabular}{lcccc}
\hline \hline \multicolumn{1}{c}{ REIT name } & Ticker & Property focus & Region & NY \\
\hline Alexandria Real Estate Equities & ARE & Office & WE & $0.00 \%$ \\
AmeriVest Properties & AMV & Office & SW & $0.00 \%$ \\
Arden Realty & ARI & Office & WE & $0.00 \%$ \\
Bedford Property Investors & BED & Office & WE & $0.00 \%$ \\
Boston Properties & BXP & Office & NE & $18.37 \%$ \\
Brandywine Realty & BDN & Office & MA & $1.75 \%$ \\
CarrAmerica Realty & CRE & Office & MA & $0.00 \%$ \\
Corporate Office Properties & OFC & Office & MA & $3.19 \%$ \\
Crescent Real Estate Equities & CEI & Office & SW & $0.00 \%$ \\
Duke Realty & DRE & Office & MW & $0.00 \%$ \\
Equity Office Properties & EOP & Office & MW & $5.18 \%$ \\
Forest City Enterprises & FCEA & Diversified / Other & MW & $38.53 \%$ \\
Glenborough Realty & GLB & Office & WE & $4.58 \%$ \\
Great lakes REIT & GL & Office & MW & $0.00 \%$ \\
Highwood Properties & HIW & Office & SE & $0.00 \%$ \\
HRPT Properties & HRP & Office & NE & $32.29 \%$ \\
Kilroy Realty & KRC & Office & WE & $0.00 \%$ \\
Koger Equity & KE & Office & SE & $0.00 \%$ \\
Lexington Properties & LXP & Diversified / Other & MA & $8.55 \%$ \\
Mack-Cali Realty & CLI & Office & MA & $61.71 \%$ \\
Mission West Properties & MSW & Office & WE & $0.00 \%$ \\
Parkway Properties & PKY & Office & SE & $0.00 \%$ \\
Prentiss Properties & PP & Office & SW & $0.00 \%$ \\
Prime Group Realty & PGE & Office & MW & $0.00 \%$ \\
Reckson Associates Realty & RA & Office & MA & $93.48 \%$ \\
SL Green Realty & SLG & Office & MA & $100.00 \%$ \\
Vornado Realty & & & DA & $43.26 \%$ \\
\hline \hline
\end{tabular}




\section{Table 2. Market reaction}

This table analyzes relative price changes of the REITs in our sample from the close on 09/10/2001 to the open and close of 09/17/2001. REITs with some NY metro exposure (see Table 1) are compared to those with none (Panel A) or to the Dow Jones Industrial Average (DJIA, Panel B), using one and two-tailed $t$-tests for average price changes and one-tailed $F$-tests for their variances. A "* " indicates significance of the $t$-statistic at the $5 \%$ level. $\mathrm{P}(\mathrm{F} \leq \mathrm{f})$ is the probability that two variances are not significantly different.

\begin{tabular}{|c|c|c|}
\hline \multicolumn{3}{|c|}{ Panel A: REIT comparison } \\
\hline & close-to-open & close-to-close \\
\hline \multicolumn{3}{|c|}{ Average price change } \\
\hline Some NY metro exposure & $1.998 \%$ & $0.390 \%$ \\
\hline No NY metro exposure & $-2.075 \%$ & $-3.366 \%$ \\
\hline t statistic & $2.647^{*}$ & $3.337^{*}$ \\
\hline $\mathrm{P}(\mathrm{T} \leq \mathrm{t})$ one-tail & 0.007 & 0.001 \\
\hline $\mathrm{t}$ critical one-tail & 1.708 & 1.708 \\
\hline $\mathrm{P}(\mathrm{T} \leq \mathrm{t})$ two-tail & 0.014 & 0.003 \\
\hline $\mathrm{t}$ critical two-tail & 2.060 & 2.060 \\
\hline \multicolumn{3}{|c|}{ Standard deviation of price change } \\
\hline Some NY metro exposure & $5.683 \%$ & $3.493 \%$ \\
\hline No NY metro exposure & $1.676 \%$ & $2.344 \%$ \\
\hline F statistic & 0.087 & 0.450 \\
\hline $\mathrm{P}(\mathrm{F} \leq \mathrm{f})$ one-tail & 0.000 & 0.081 \\
\hline $\mathrm{F}$ critical one-tail & 0.390 & 0.390 \\
\hline \multicolumn{3}{|c|}{ Panel B: NY REITs versus DJIA } \\
\hline & close-to-open & close-to-close \\
\hline \multicolumn{3}{|c|}{ Average price change } \\
\hline Some NY metro exposure & $1.998 \%$ & $0.390 \%$ \\
\hline DJIA & $-6.798 \%$ & $-8.119 \%$ \\
\hline t statistic & $4.095^{*}$ & $3.667^{*}$ \\
\hline $\mathrm{P}(\mathrm{T} \leq \mathrm{t})$ one-tail & 0.000 & 0.000 \\
\hline t critical one-tail & 1.684 & 1.684 \\
\hline $\mathrm{P}(\mathrm{T} \leq \mathrm{t})$ two-tail & 0.000 & 0.000 \\
\hline t critical two-tail & 2.021 & 2.021 \\
\hline \multicolumn{3}{|c|}{ Average standard deviation of price change } \\
\hline Some NY metro exposure & $5.683 \%$ & $3.493 \%$ \\
\hline DJIA & $6.505 \%$ & $7.682 \%$ \\
\hline F statistic & 0.763 & 0.207 \\
\hline $\mathrm{P}(\mathrm{F} \leq \mathrm{f})$ one-tail & 0.328 & 0.004 \\
\hline F critical one-tail & 0.388 & 0.388 \\
\hline
\end{tabular}




\section{Table 3. Cross-sectional REIT correlations}

This table reports cross-sectional correlations between observed price changes (from the close on Monday September 10, 2001 to the open of Monday September 17, 2001) for the REITs in our sample, their square footage in the New York metropolitan area (NY metro, including Northern NJ, Southern CT, Long Island, and Westchester, but excluding downtown Manhattan), their percentage square footage of office space in New York City (PctNYC, computed as the ratio between New York City office square feet and square feet of office space in the entire REIT portfolio), and their percentage square footage in the entire New York metropolitan area (PctNYMetro, computed as the ratio between New York metropolitan office square feet, excluding Manhattan, and square feet of office space in the entire REIT portfolio).

\begin{tabular}{r|cccc}
\hline \hline & Price change & NY metro & PctNYC & PctNYMetro \\
\cline { 2 - 6 } Price change & 1.000 & & & \\
NY metro & 0.827 & 1.000 & & \\
PctNYC & 0.603 & 0.644 & 1.000 & \\
PctNYMetro & 0.781 & 0.842 & 0.746 & 1.000 \\
\hline \hline
\end{tabular}




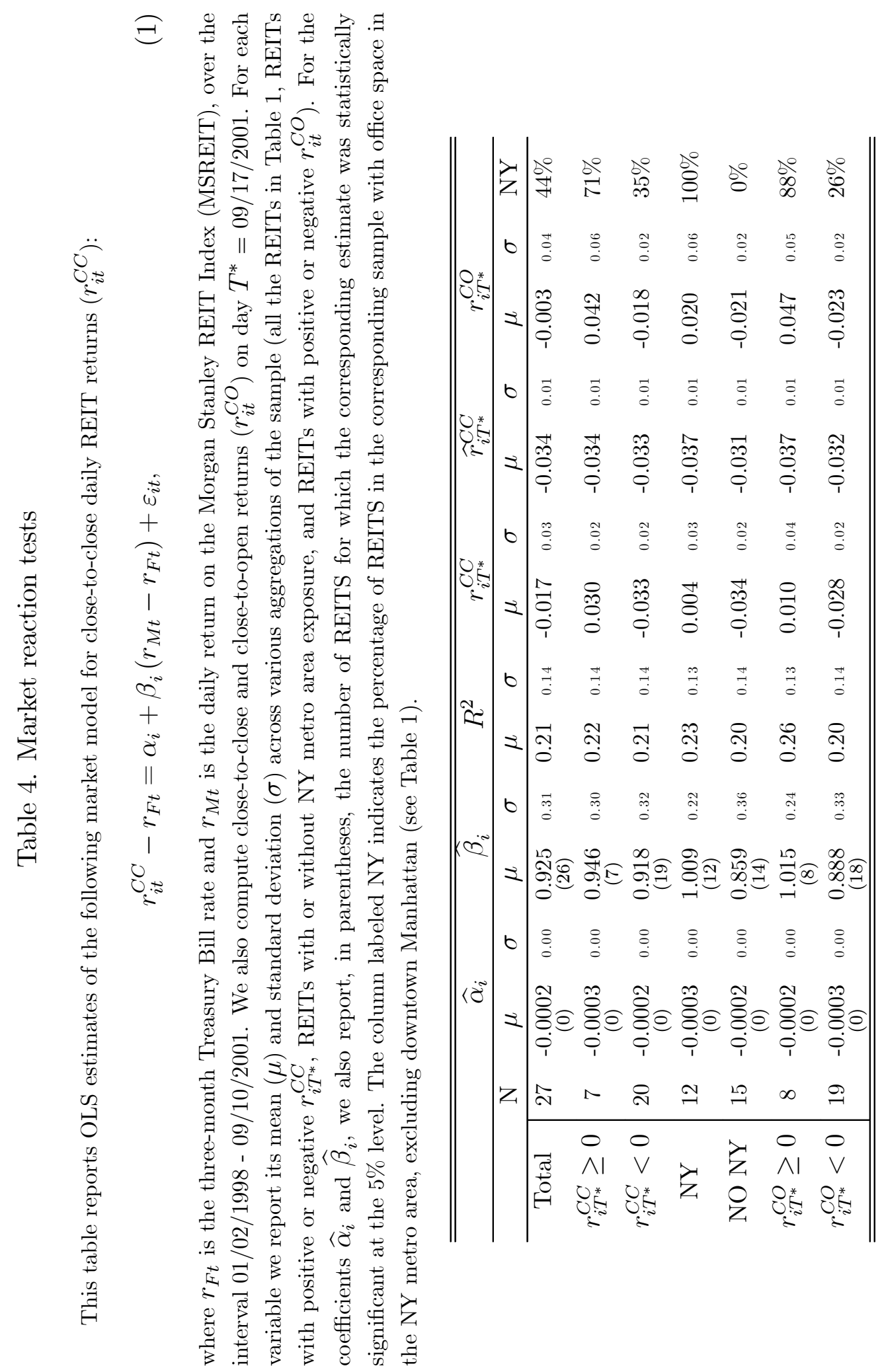


Table 5a. Real asset behavior: NAV, IRR, \& blend cap rates

This table reports estimates of excess quarterly REIT internal rates of return (or IRR $\left.\left(i r r_{i \tau}\right)\right)$ for 2001.Q4. Excess IRRs are computed in three steps. First, we estimate the following market model for the New York City IRR Index $\left(i r r_{N Y \tau}\right)$ :

$$
i r r_{\tau}^{N Y}-r_{F \tau}=\alpha+\beta\left(r_{U S \tau}-r_{F \tau}\right)+\eta_{\tau}
$$

where $r_{F \tau}$ is the three-month Treasury Bill rate and $r_{U S \tau}$ is the quarterly U.S. IRR Index from Korpacz Data (computed on unleveraged, all cash transactions). The model of Eq. (2) is estimated over 29 quarterly observations between 1994.Q2 and 2001.Q2. Second, the resulting coefficients' OLS estimates, $\widehat{\alpha}=0.0027$ (and a $t$-statistic of 2.27) and $\widehat{\beta}=0.8305$ (and a $t$-statistic of 11.66), with $R^{2}=83.43 \%$, are then used to measure the "normal" NY IRR $\widehat{i r r}_{\tau}^{N Y}$. Finally, excess IRR for each REIT when $\tau^{*}$ $=2001 . \mathrm{Q} 4$ is computed as the difference between the percentage quarterly change in Net Asset Value (NAV) per share with respect to 2001.Q3, $i r r_{i \tau^{*}}$, and its benchmark $i r r_{i \tau^{*}}^{B}=\omega_{i} \widehat{\operatorname{irr}}_{\tau^{*}}^{N Y}+\left(1-\omega_{1}\right) r_{U S \tau^{*}}$, where $\omega_{i}$ is the percentage of the REIT $i$ 's office space in the NY metro area reported in Table 1. Each REIT's NAV is computed as the ratio between its TTMNOI and its blend cap rate. A REIT's TTMNOI is the difference between its Trailing Twelve Months Total Rental Revenue and its Property Operating Revenues. Individual blend cap rates are weighted averages of either actual (from NREI and ACLI) or expectational (from PWC) weighted cap rates for both New York and the U.S. (see Section 2), with weights given by the REIT's exposure to the NY metro area (in Table 1). NEVs per share are computed to control for the possibility that the REITs added properties to their portfolios and financed the purchase with a secondary stock offering. For each excess IRR we report its mean $(\mu)$ and standard deviation $(\sigma)$ across various subsets of the sample (all REITs in Table 1, REITs with positive or negative $r_{i T^{*}}^{C C}$, REITs with or without NY metro area exposure, and REITs with positive or negative $r_{i T^{*}}^{C O}$, where $\left.T^{*}=09 / 17 / 2001\right)$. The column labeled NY indicates the corresponding percentage of REITs with office space in the NY metro area, excluding downtown Manhattan. A "* " and "** " indicate significance at the $10 \%$ and $5 \%$ level, respectively.

\begin{tabular}{c|cccccccc}
\hline \hline \multicolumn{7}{c}{$i r r_{i \tau^{*}}^{N R E I}-i r r_{i \tau^{*}}^{B}$} & $i r r_{i \tau^{*}}^{A C L I}-i r r_{i \tau^{*}}^{B}$ & $i r r_{i \tau^{*}}^{P W C}-i r r_{i \tau^{*}}^{B}$ \\
\hline \multicolumn{1}{c}{$\mathrm{N}$} & $\mu$ & $\sigma$ & $\mu$ & $\sigma$ & $\mu$ & $\sigma$ & $\mathrm{NY}$ \\
\hline Total & 27 & $-0.048^{* *}$ & 0.09 & -0.013 & 0.09 & $-0.034^{*}$ & 0.09 & $44 \%$ \\
$r_{i T^{*}}^{C C} \geq 0$ & 7 & -0.024 & 0.05 & 0.014 & 0.06 & -0.026 & 0.05 & $71 \%$ \\
$r_{i T^{*}}^{C C}<0$ & 20 & $-0.057^{* *}$ & 0.10 & -0.022 & 0.10 & -0.037 & 0.11 & $35 \%$ \\
$\mathrm{NY}$ & 12 & $-0.033^{* *}$ & 0.04 & 0.004 & 0.04 & $-0.030^{* *}$ & 0.04 & $100 \%$ \\
$\mathrm{NO} \mathrm{NY}$ & 15 & $-0.060^{*}$ & 0.12 & -0.026 & 0.12 & -0.038 & 0.12 & $0 \%$ \\
$r_{i T^{*}}^{C O} \geq 0$ & 8 & $-0.029^{*}$ & 0.04 & 0.009 & 0.05 & $-0.036^{* *}$ & 0.03 & $88 \%$ \\
$r_{i T^{*}}^{C O}<0$ & 19 & $-0.056^{* *}$ & 0.11 & -0.022 & 0.10 & -0.034 & 0.11 & $26 \%$ \\
\hline \hline
\end{tabular}


Table 5b. Real asset behavior: NAV, IRR, \& U.S. cap rates

This table reports estimates of excess quarterly REIT internal rates of return (or IRR $\left.\left(i r r_{i \tau}\right)\right)$ for 2001.Q4. Excess IRRs are computed in three steps. First, we estimate the following market model for the New York City IRR Index $\left(i r r_{N Y \tau}\right)$ :

$$
i r r_{\tau}^{N Y}-r_{F \tau}=\alpha+\beta\left(r_{U S \tau}-r_{F \tau}\right)+\eta_{\tau}
$$

where $r_{F t}$ is the three-month Treasury Bill rate and $r_{U S \tau}$ is the quarterly U.S. IRR Index from Korpacz Data (computed on unleveraged, all cash transactions). The model of Eq. (2) is estimated over 29 quarterly observations between 1994.Q2 and 2001.Q2. Second, the resulting coefficients' OLS estimates, $\widehat{\alpha}=0.0027$ (and a $t$-statistic of 2.27) and $\widehat{\beta}=0.8305$ (and a $t$-statistic of 11.66), with $R^{2}=83.43 \%$, are then used to measure the "normal" NY IRR $\widehat{i r r}_{\tau}^{N Y}$. Finally, excess IRR for each REIT when $\tau^{*}$ $=2001 . \mathrm{Q} 4$ is computed as the difference between the percentage quarterly change in Net Asset Value (NAV) per share with respect to 2001.Q3, $i r r_{i \tau^{*}}$, and its benchmark $i r r_{i \tau^{*}}^{B}=\omega_{i} \widehat{i r r}_{\tau^{*}}^{N Y}+\left(1-\omega_{1}\right) r_{U S \tau^{*}}$, where $\omega_{i}$ is the percentage of the REIT $i$ 's office space in the NY metro area reported in Table 1. Each REIT's NAV is computed as the ratio between its TTMNOI and the U.S. cap rate. A REIT's TTMNOI is the difference between its Trailing Twelve Months Total Rental Revenue and its Property Operating Revenues. Individual U.S. cap rates are either actual (from NREI and ACLI) or expectational (from PWC) cap rates for the U.S. (see Section 2). NEVs per share are computed to control for the possibility that the REITs added properties to their portfolios and financed the purchase with a secondary stock offering. For each excess IRR we report its mean $(\mu)$ and standard deviation $(\sigma)$ across various subsets of the sample (all REITs in Table 1, REITs with positive or negative $r_{i T^{*}}^{C C}$, REITs with or without NY metro area exposure, and REITs with positive or negative $r_{i t}^{C O}$, where $\left.T^{*}=09 / 17 / 2001\right)$. The column labeled NY indicates the corresponding percentage of REITs with office space in the NY metro area, excluding downtown Manhattan. A "* " and "** " indicate significance at the $10 \%$ and $5 \%$ level, respectively.

\begin{tabular}{|c|c|c|c|c|c|c|c|c|}
\hline & & \multicolumn{2}{|c|}{$\overline{i r r_{i \tau^{*}}^{N R E I}-i r r_{i \tau^{*}}^{B}}$} & \multicolumn{2}{|c|}{$\overline{i r r_{i \tau^{*}}^{A C L I}-i r r_{i \tau^{*}}^{B}}$} & \multicolumn{2}{|c|}{$\overline{c i r r_{i \tau^{*}}^{P W C}-i r r_{i \tau^{*}}^{B}}$} & \\
\hline & $\mathrm{N}$ & $\mu$ & $\sigma$ & $\mu$ & $\bar{\sigma}$ & $\mu$ & $\sigma$ & NY \\
\hline Total & 27 & $-0.059^{* *}$ & 0.09 & -0.026 & 0.09 & $-0.033^{*}$ & 0.09 & $44 \%$ \\
\hline$r_{i T^{*}}^{C C} \geq 0$ & 7 & $-0.049^{* *}$ & 0.05 & -0.016 & 0.05 & -0.023 & 0.05 & $71 \%$ \\
\hline$r_{i T^{*}}^{C C}<0$ & 20 & $-0.063^{* *}$ & 0.11 & -0.029 & 0.11 & -0.037 & 0.11 & $35 \%$ \\
\hline NY & 12 & $-0.054^{* *}$ & 0.04 & $-0.020^{*}$ & 0.04 & $-0.028^{* *}$ & 0.04 & $100 \%$ \\
\hline NO NY & 15 & $-0.064^{*}$ & 0.12 & -0.030 & 0.12 & -0.038 & 0.12 & $0 \%$ \\
\hline$r_{i T^{*}}^{C O} \geq 0$ & 8 & $-0.059^{* *}$ & 0.03 & $-0.026^{*}$ & 0.03 & $-0.033^{* *}$ & 0.03 & $88 \%$ \\
\hline$r_{i T^{*}}^{C O}<0$ & 19 & $-0.059^{* *}$ & 0.11 & -0.026 & 0.11 & -0.033 & 0.11 & $26 \%$ \\
\hline
\end{tabular}


Table 6. Analysts' recommendations for Mack-Cali (CLI)

This table displays various analysts' assessment of the impact of the WTC attacks on Mack-Cali (CLI) and their subsequent recommendations, from Investext. We collect analysts' reports issued immediately prior to the attack, issued 10 days subsequent to the attack (highlighted), and published one to three quarters after the event.

\begin{tabular}{|c|c|c|c|c|c|c|c|}
\hline $\begin{array}{l}\text { REIT: Mack- Ca } \\
\text { Date of Report }\end{array}$ & ali (CLl) & Recommendation & $\begin{array}{c}\text { Change of } \\
\text { Target }\end{array}$ & $\begin{array}{l}\text { Price } \\
\text { Target }\end{array}$ & EPS $01 E$ & EPS $02 E$ & EPS $03 E$ \\
\hline 16-Aug-01 & Morgan Stanley & Underperform & $\$ 26$ to $N A$ & NA & 3.64 & 3.81 & -- \\
\hline 18-Sep-01 & Morgan Stanley & Outperform & NA to $\$ 32$ & 32 & 3.66 & 3.89 & -- \\
\hline 12-Nov-01 & Morgan Stanley & Neutral & $\$ 32$ to $N A$ & NA & 3.66 & 3.74 & -- \\
\hline 22-Feb-02 & Morgan Stanley & Neutral & NA to $\$ 31.50$ & 31.50 & 3.66 & 3.74 & 3.97 \\
\hline 9-May-02 & Morgan Stanley & Equal Weight & $\$ 33$ to $\$ 33.50$ & 33.50 & -- & 3.73 & 3.97 \\
\hline 9-Aug-01 & Lehman Brothers & Market Perform & & 30 & 3.65 & 3.89 & -- \\
\hline 2-0ct-01 & Lehman Brothers & Buy & & 34 & 3.67 & 3.96 & -- \\
\hline 9-Now-01 & Lehman Brothers & Buy & & 34 & 3.64 & 3.81 & -- \\
\hline 10-Jan-02 & Lehman Brothers & Buy & & 33 & -- & 3.81 & 4.08 \\
\hline 21-Feb-02 & Lehman Brothers & Buy & & 33 & -- & 3.81 & 4.08 \\
\hline 8-May-02 & Lehman Brothers & Buy & & 34 & -- & 3.75 & 4.00 \\
\hline 10-Jun-02 & Lehman Brothers & Market Perform & & 34 & -- & 3.75 & 3.95 \\
\hline 10-Aug-01 & Banc of America & Underperform & & NA & 3.68 & 3.96 & - \\
\hline 21-Sep-01 & Banc of America & Market Performer & NA to $\$ 32$ & 32 & 3.70 & 4.02 & \\
\hline 8-Now-01 & Banc of America & Market Performer & $\$ 32$ to NA & NA & 3.66 & 3.77 & -- \\
\hline 22-Feb-02 & Banc of America & Market Performer & & NA & -- & 3.74 & 4.05 \\
\hline 7-May-02 & Banc of America & Market Performer & & NA & -- & 3.72 & 3.99 \\
\hline 10-Aug-01 & Salomon Smith Barney & Neutral & & 30 & 3.67 & 3.90 & -- \\
\hline 21-Sep-01 & Salomon Smith Barney & Outperform & & 33 & 3.67 & 4.10 & -- \\
\hline 8-Nor-01 & Salomon Smith Barney & Outperform & & 33 & -- & 3.73 & 4.12 \\
\hline 25-Feb-02 & Salomon Smith Barney & Outperform & & 33 & -- & 3.72 & 4.00 \\
\hline 20-Mar-02 & Salomon Smith Barney & Outperform & & 34 & -- & 3.72 & 4.00 \\
\hline 7-May-02 & Salomon Smith Barney & Outperform & & 36 & -- & 3.72 & 4.00 \\
\hline 10-Aug-01 & Deutsche Banc & Market Perform & & 28 & 3.65 & 3.80 & -- \\
\hline 8-Nor-01 & Deutsche Banc & Buy & & NA & 3.65 & 3.80 & -- \\
\hline 9-Nor-01 & Deutsche Banc & Market Perform & & NA & 3.65 & 3.70 & -- \\
\hline 25-Feb-02 & Deutsche Banc & Market Perform & & NA & -- & 3.70 & 3.95 \\
\hline 7-May-02 & Deutsche Banc & Market Perform & & NA & -- & 3.70 & 3.95 \\
\hline 30-Mar-01 & CS First Boston & Hold & & NA & NA & NA & -- \\
\hline 18-Sep-01 & CS First Boston & Strong Buy & & 34.50 & 3.65 & 3.85 & -- \\
\hline 8-May-02 & CS First Boston & Buy & & 38 & -- & 3.73 & 3.92 \\
\hline 24-Jun-02 & CS First Boston & Buy & & 38 & -- & 3.73 & 3.92 \\
\hline
\end{tabular}




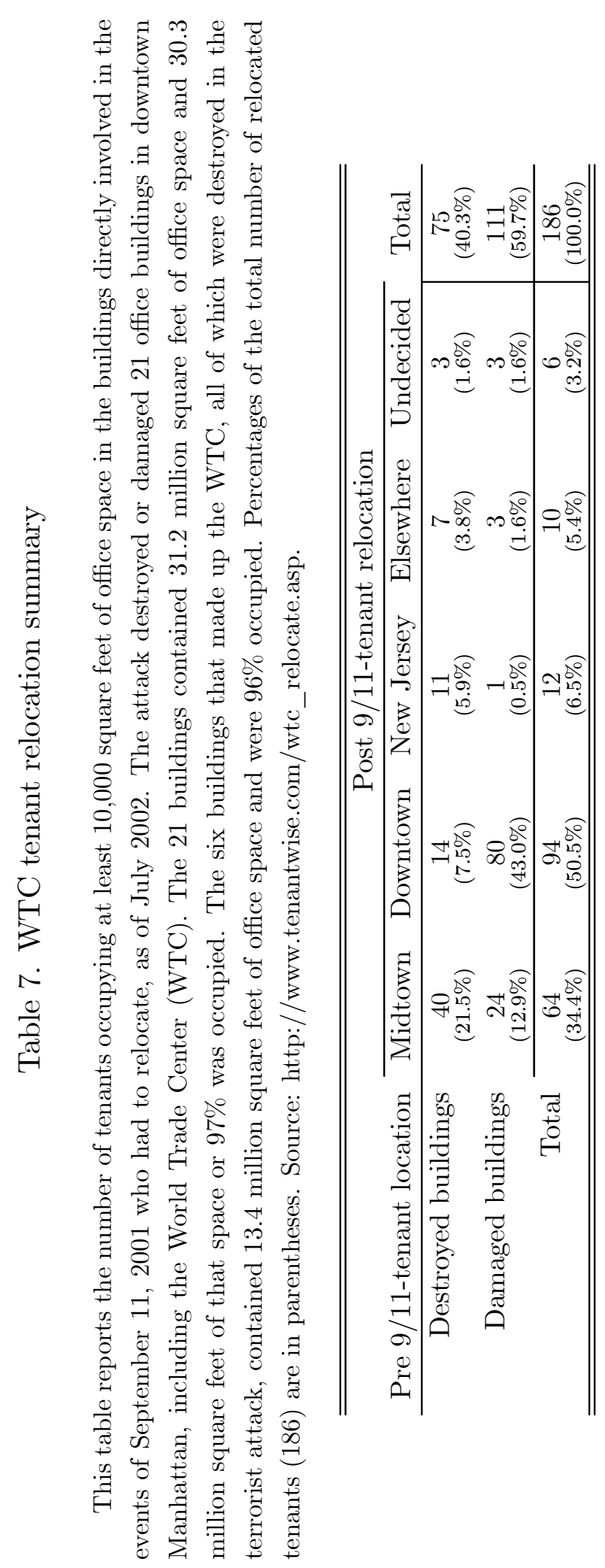




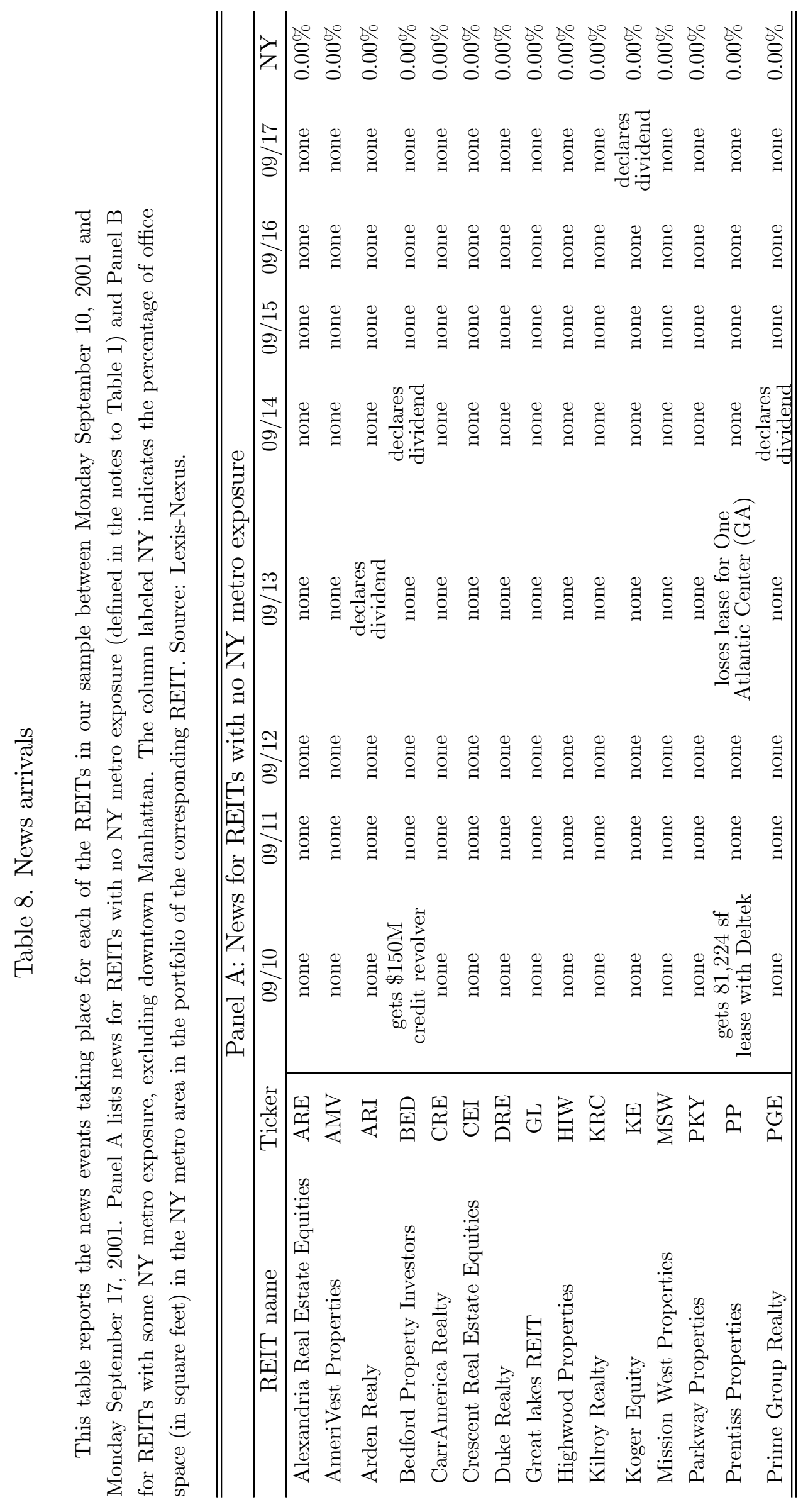




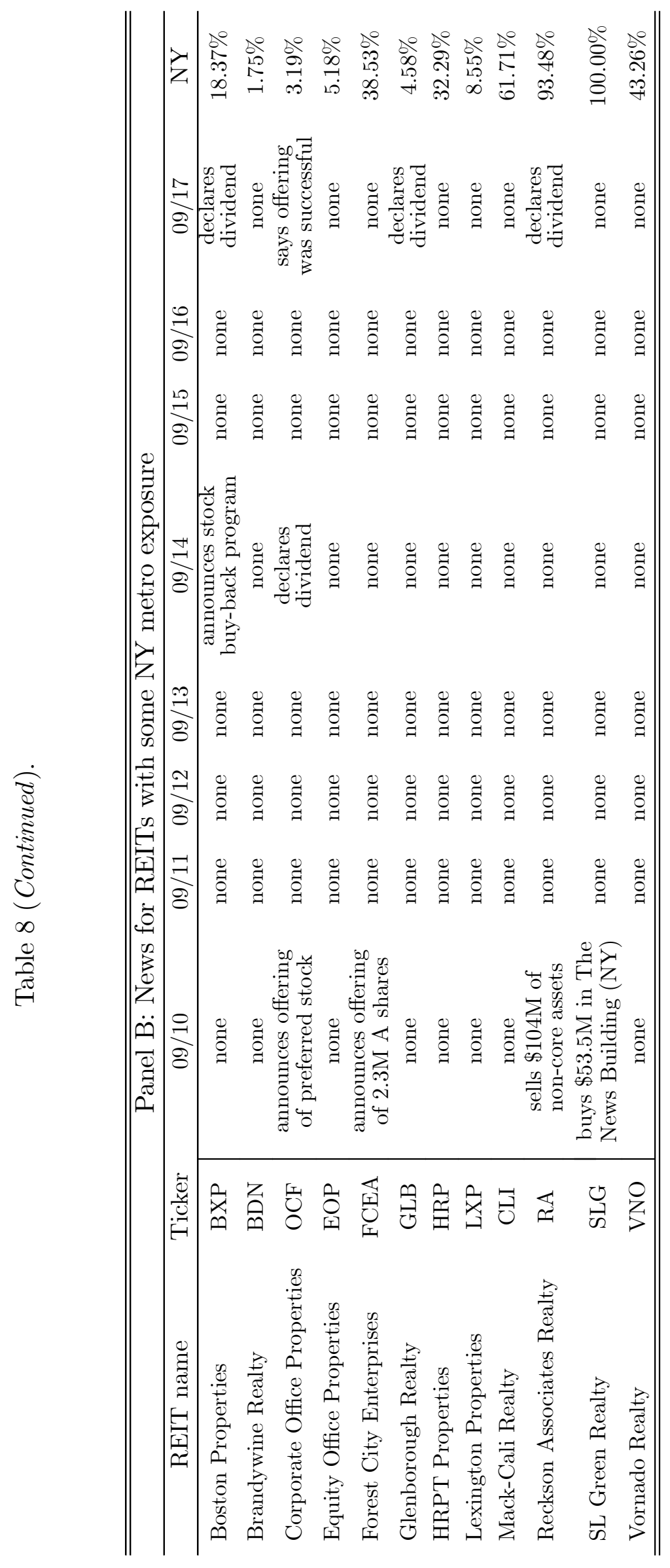




\section{Figure 1. Price changes for office REITs}

These figures plot the price change for each of the REITs in our sample, from the close on Monday September 10, 2001 to the open on Monday September 17, 2001, with respect to their corresponding amount of office space in the NY metro area (excluding downtown Manhattan), measured in square feet (000s, Figure 1a) and in percentage of total square footage (Figure 1b).

a) Square feet of office space

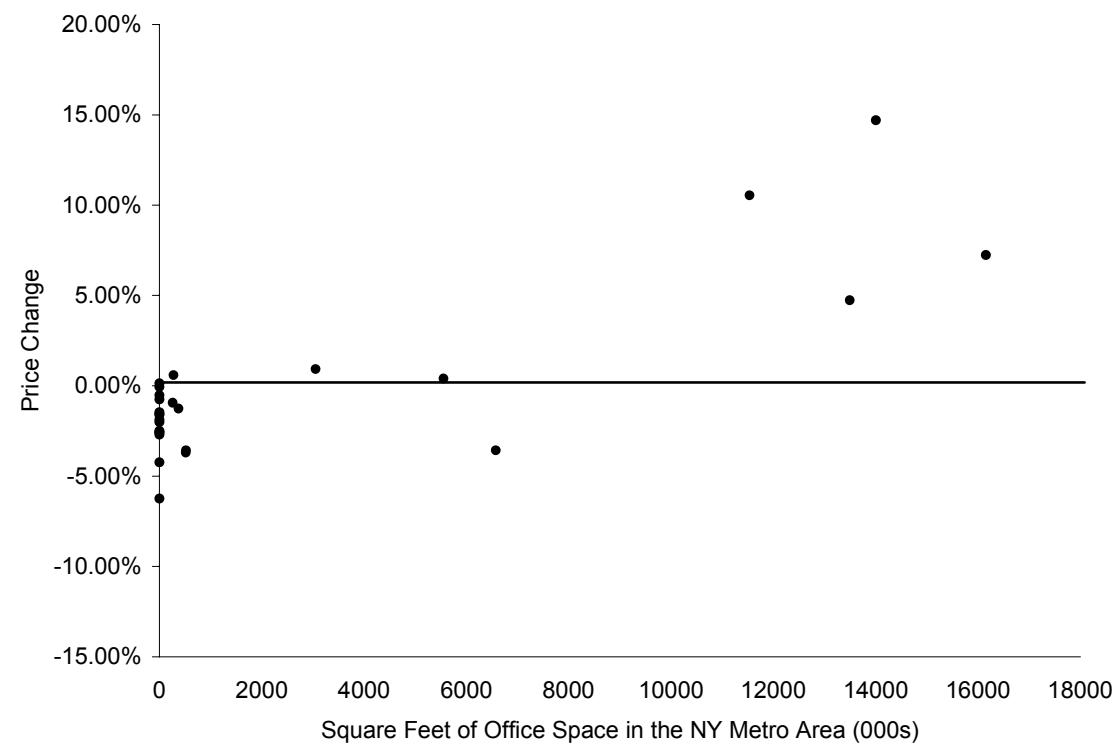

b) Percent of office space

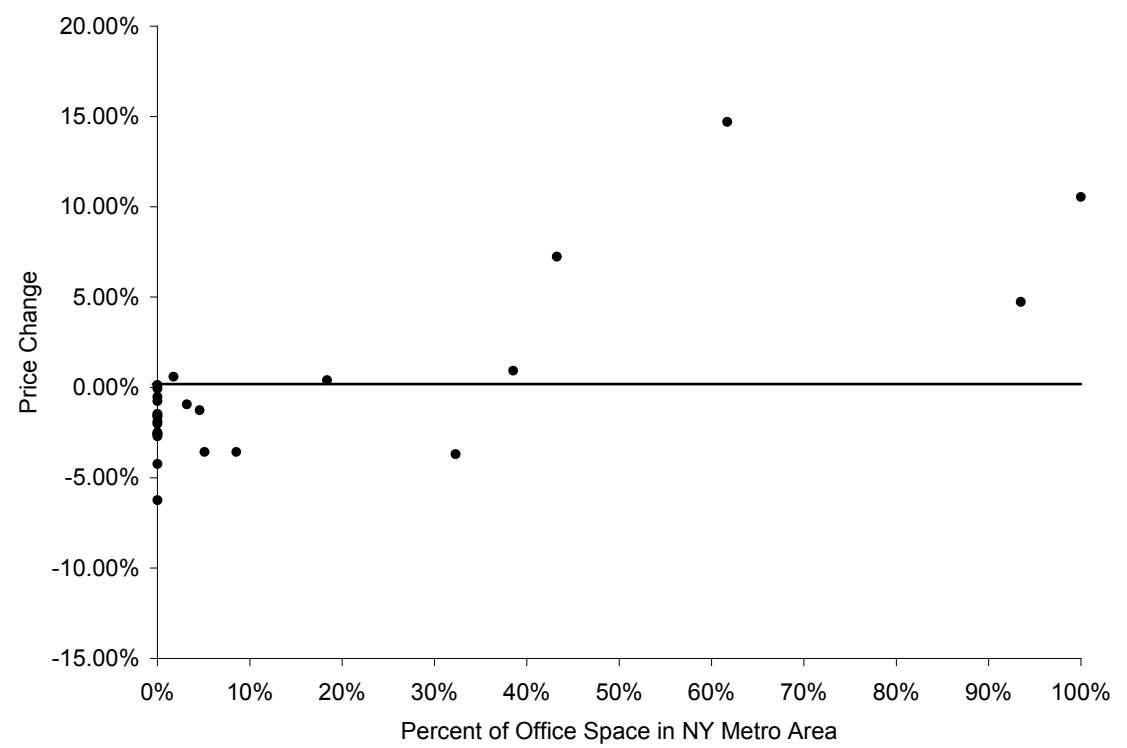




\section{Figure 2. Insider trading: NY REITs versus NO NY REITs}

This figure displays the cumulative sums of the ratios $\frac{B U Y_{t}-S E L L_{t}}{B U Y_{t}+S E L L_{t}}$, where $B U Y_{t}$ and $S E L L_{t}$ are the total number of shares bought and sold, respectively, by insiders in month $t$, between January 2001 and March 2002, for the REITs in our sample with some exposure to the NY metro area excluding downtown Manhattan (NY, solid line) and for the REITs with no such exposure (NO NY, dashed line), described in Table 1. The data are obtained from WRDS (Wharton Research Data Services) TFN Insider Filing Data Files, which contain all insider activity as reported on SEC forms 3, 4, 5, and 144.

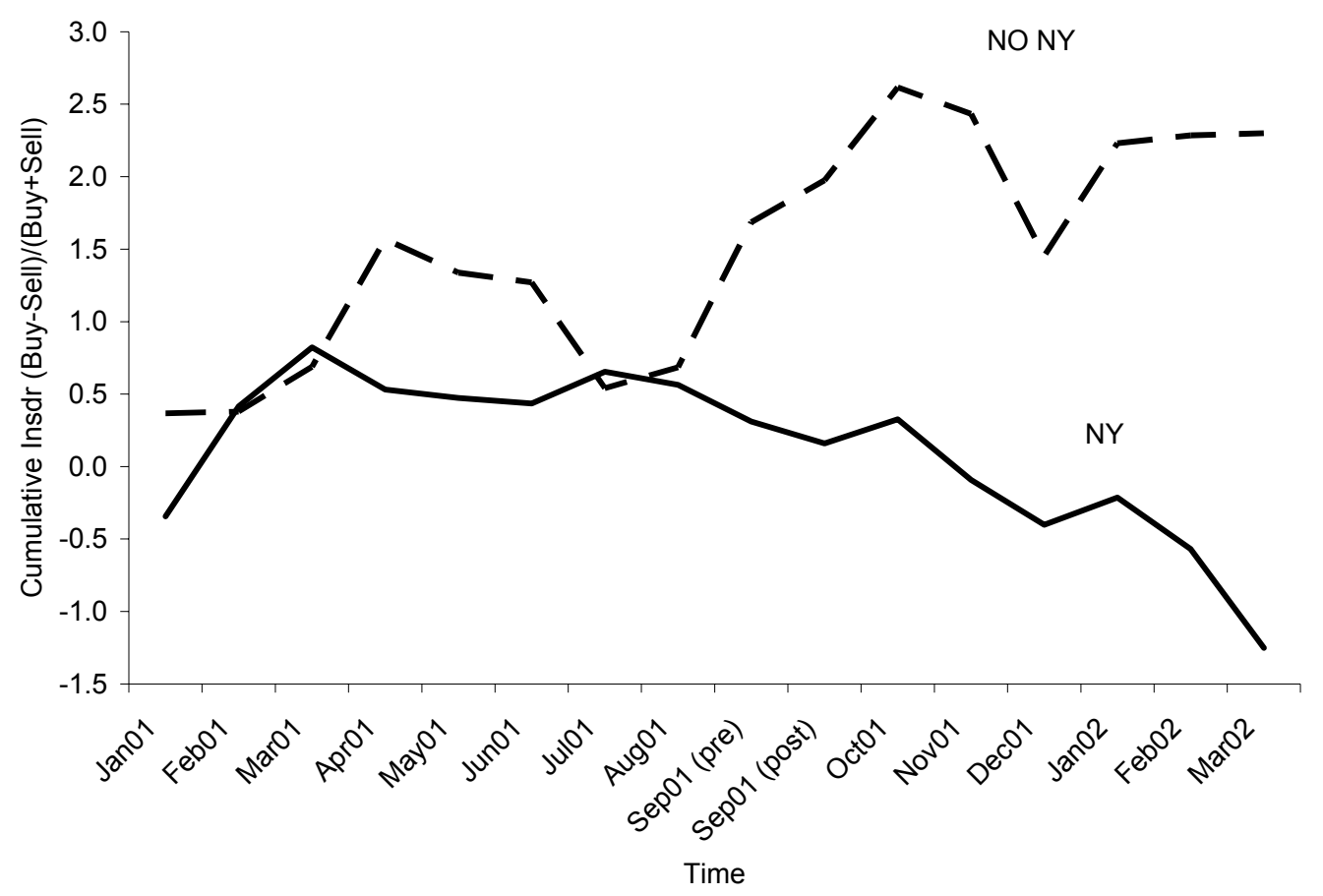


Figure 3. Cumulative abnormal returns for NY REITs

This figure plots cumulative abnormal returns (CARs, solid line) for the 12 REITs with some exposure to the NY metro office market excluding downtown Manhattan (NY) over the interval 09/17/2001 - 06/17/2002. The CAR series are generated by first estimating the following market model for close-to-close daily REIT returns $\left(r_{i t}^{C C}\right)$ :

$$
r_{i t}^{C C}-r_{F t}=\alpha_{i}+\beta_{i}\left(r_{M t}-r_{F t}\right)+\varepsilon_{i t}
$$

where $r_{F t}$ is the three-month Treasury Bill rate and $r_{M t}$ is the daily return on the Morgan Stanley REIT Index (MSREIT), over the interval 01/02/1998 - 09/10/2001 (as reported in Table 4), then computing abnormal returns (ARs) from Eq. (1) as the difference $r_{i t}^{C C}-\widehat{r}_{i t}^{C C}$ for each of the REITs in the two subsamples, and finally cumulating ARs over time and aggregating them across REITs. We also show $95 \%$ confidence intervals (dashed lines) under the null hypothesis of zero CARs.

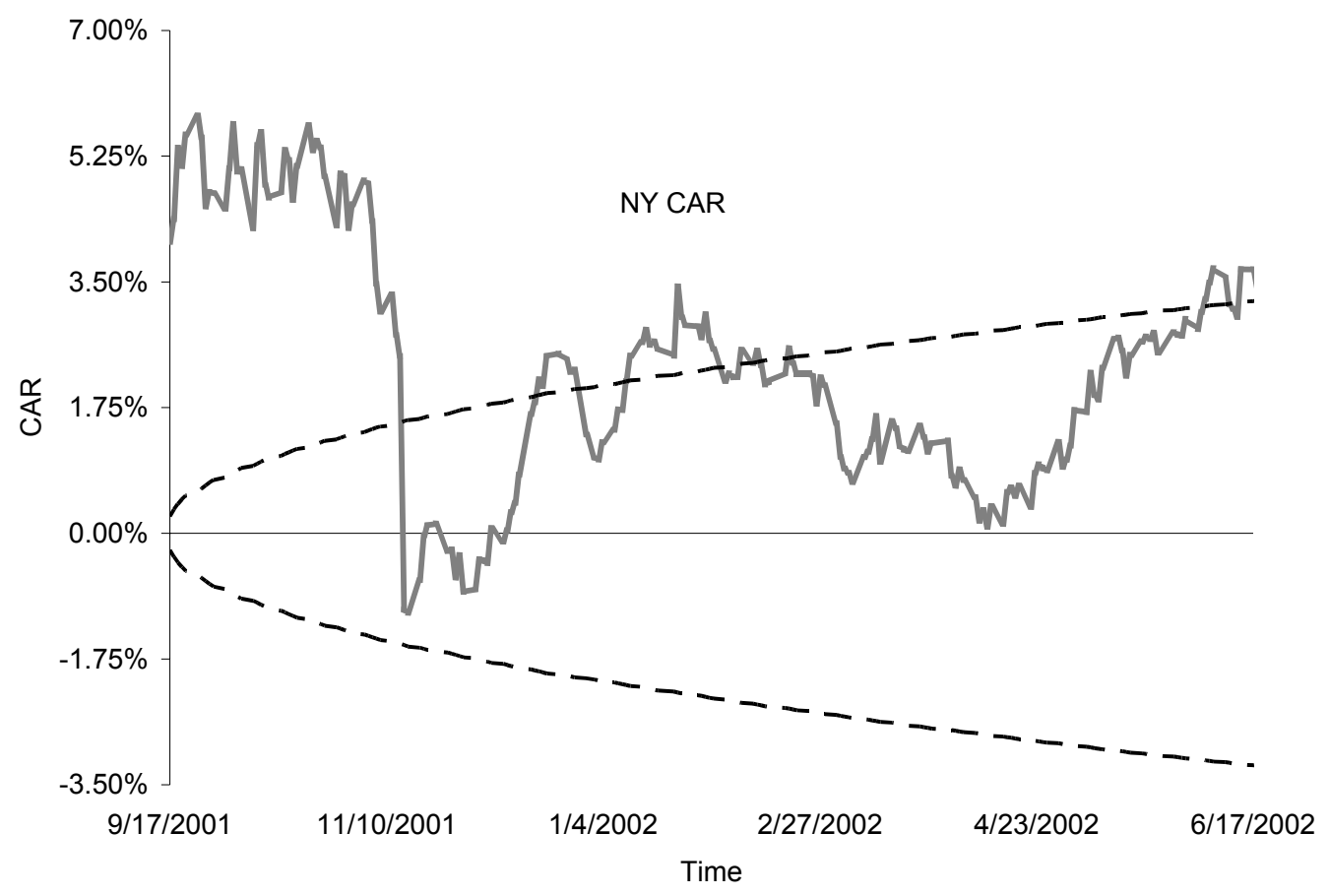

